\title{
Sanguinaria canadensis: Traditional Medicine, Phytochemical Composition, Biological Activities and Current Uses
}

\author{
Andrew Croaker ${ }^{1, *}$, Graham J. King ${ }^{1}$, John H. Pyne ${ }^{2}$, Shailendra Anoopkumar-Dukie ${ }^{3}$ and \\ Lei Liu ${ }^{1, *}$ \\ 1 Southern Cross Plant Science, Southern Cross University, Lismore, NSW 2480, Australia; \\ graham.king@scu.edu.au \\ 2 School of Medicine, The University of Queensland, St. Lucia, QLD 4072, Australia; j.pyne@uq.edu.au \\ 3 School of Pharmacy, Griffith University, Gold Coast Campus, Gold Coast, QLD 4222, Australia; \\ s.dukie@griffith.edu.au \\ * Correspondence: a.croaker.10@student.scu.edu.au (A.C.); lliu@scu.edu.au (L.L.); \\ Tel.: +61-04-2959-4932 (A.C.); +61-02-6622-3211 (L.L.)
}

Academic Editor: Chang Won Choi

Received: 22 July 2016; Accepted: 12 August 2016; Published: 27 August 2016

\begin{abstract}
Sanguinaria canadensis, also known as bloodroot, is a traditional medicine used by Native Americans to treat a diverse range of clinical conditions. The plants rhizome contains several alkaloids that individually target multiple molecular processes. These bioactive compounds, mechanistically correlate with the plant's history of ethnobotanical use. Despite their identification over 50 years ago, the alkaloids of $S$. canadensis have not been developed into successful therapeutic agents. Instead, they have been associated with clinical toxicities ranging from mouthwash induced leukoplakia to cancer salve necrosis and treatment failure. This review explores the historical use of S. canadensis, the molecular actions of the benzophenanthridine and protopin alkaloids it contains, and explores natural alkaloid variation as a possible rationale for the inconsistent efficacy and toxicities encountered by S. canadensis therapies. Current veterinary and medicinal uses of the plant are studied with an assessment of obstacles to the pharmaceutical development of $S$. canadensis alkaloid based therapeutics.
\end{abstract}

Keywords: black salve; sanguinarine; Sanguinaria canadensis; bloodroot; herbal; escharotic; skin cancer; alkaloid

\section{Introduction}

A number of pharmaceutical compounds have been developed from natural products used as traditional medicines [1]. Sanguinaria canadensis is a herbaceous North American plant with a history of ethnobotanical use [2]. The rhizome of the plant, also known as bloodroot because of its red latex, contains a number of biologically active alkaloids that have been investigated as potential drug candidates [3]. Despite their elucidation over 50 years ago [4], and significant activity in a range of molecular pathways, the individual alkaloids of $S$. canadensis are yet to find utility as proven human therapeutics [5,6].

S. canadensis contains eight isoquinoline alkaloids at biologically relevant concentrations including six quaternary benzophenanthridine alkaloids (QBAs) sanguinarine, chelerythrine, sanguilutine, chelilutine, sanguirubine, chelirubine and two protopin alkaloids protopine and allocryptopine (Figure 1) [7]. Most reports regarding these alkaloids discuss their anticancer effects, especially for sanguinarine and chelerythrine [8], although antimicrobial [9], cardiovascular [10], neuroreceptor [11] and anti-inflammatory activities [12] of these alkaloids have also been identified. 
<smiles>C[n+]1cc2c3c(ccc2c2ccc4cc5c(cc4c21)OCO5)OCO3</smiles><smiles>COc1cc2ccc3c4c(OC)cc(OC)c(OC)c4c[n+](C)c3c2cc1OC</smiles>

Sanguilutine<smiles></smiles>

Sanguirubine<smiles>CN(C)CC1=C2CC(=O)c3cc4c(cc3CCN(C)C=CC3OCOC13)C2OCO4</smiles>

Protopine<smiles></smiles>

Chelerythrine<smiles></smiles>

Chelilutine<smiles></smiles>

Chelirubine<smiles>COc1ccc2c(c1OC)CN(C)CCc1cc3c(cc1C(=O)C2)OCO3</smiles>

Allocryptopine

Figure 1. Chemical structures of biologically active S. canadensis alkaloids.

With its promising biological activities, S. canadensis containing products have been used in vivo as livestock feed supplements [13], dental antibacterial agents [14], homeopathic arthritis [15] and skin cancer treatments [16]. The human use of S. canadensis containing therapeutics has been controversial. Mouth washes containing bloodroot alkaloids were in clinical use but subsequently found to induce leukoplakia and withdrawn from sale [17]. As a self-administered skin cancer cure, topical bloodroot therapies known as black salve have been associated with toxicity [18] and therapeutic failures [19].

Being based on a plant extract, the natural variation of biologically active alkaloids in S. canadensis may contribute to these unpredictable clinical effects. A number of factors including plant maturity, harvest season, growing environment and genetics have been found to influence the composition and concentration of these alkaloids [20]. Bloodroot harvested from separate geographic locations can exhibit significant alkaloid profile variation with individual rhizomes having an up to 15-fold difference in sanguinarine concentration [21]. Such botanical variation could inadvertently carry over to therapeutic products where the concentration of active compounds needs to be high enough to achieve desired clinical effects but not exceed levels likely to cause toxicity.

Understanding the molecular action of the phytochemicals in S. canadensis assists in identifying potential plant uses and mechanisms of toxicity. Previous reviews on bloodroot alkaloids have focused on the activity of individual compounds [22] or an aspect of their biological action [23]. As vintage drug leads, some having suspected normal cell cytotoxicity [24] and mutagenic potential [25], it is 
unclear whether the alkaloids from S. canadensis will be able to transition from bench to bedside. Drug discovery efforts have recently broadened to include multicomponent drug regimens acting in concert on multiple targets [26]. This review explores the clinically relevant alkaloids present in S. canadensis. Identifying the synergistic and antagonistic effects of bloodroot compounds may facilitate the development of a lower toxicity polypharmaceutical product.

\section{Botany of S. canadensis}

Correct identification and understanding of S. canadensis is critically important for the research and development of this herb into a therapeutic product. Bloodroot (Sanguinaria canadensis Linn.) is a flowering herbaceous perennial, native to eastern North America. Its range extends in a patchy distribution from Florida to Nova Scotia and west to the Rocky Mountains [27]. It is one of the earliest plants to flower in spring covering woodland areas with white flowers. Bloodroot is a member of the Papaveraceae, a family of lactiferous latex producing plants. Cutting the rhizome releases a red blood-like sap from which the plant derives its name.

The first documented botanical description of S. canadensis occurred in the work Historia Plantarum Canadensium by Cornuti in 1635, where the plant was named Chelidonium americanum flore albo [28]. Other names were proposed for the species with Rannunculus virginiensis albus suggested by Parkinson in 1640 [29] and Papaver corniculatum suggested by Plunkenet in 1696 [30]. It was the French florist Pierre Morin in 1651 who suggested the name Sanguinaria, derived from the Latin sanguis meaning blood in recognition of the rhizomes latex, and canadensis describing a region of the plants range [31].

Johann Jacob Dillenius, a Professor of Botany at Oxford University, first recognized the plant was a unique genus [32], while Linnaeus is credited with defining the genus in his book "Species Plantarum" where he reduced several Dillenius species to one under the name Sanguinaria canadensis [33]. Rafenesque subsequently identified several varieties Parviflora, Cespitosa, Reniformis, Repens, Multipetala (double petals) and Stenopetala (narrow linear petals) [34].

Bloodroot flowers are hermaphroditic being able to self-pollinate or cross-pollinate. Self-pollination cannot occur during the initial female phase as the stamens are positioned to avoid stigma contact. During this 1-3 day period, bees are the main pollinators. If pollination has not occurred after this time, the stamens bend down contacting the stigma which results in self-pollination [35]. Flowering, in the Northern hemisphere, lasts a few days and occurs from March until May with fruiting in June.

Bloodroot seed pods develop from May through early July. The seeds they contain are round, shiny red and half surrounded by a white vermiform raphe. Approximately 50 seeds are released from each oblong pod through two uplifting valves [36].

S. canadensis is a myrmecochore relying on seed dispersal by ants [37]. Myrmecochorous plants are distributed throughout the world but are concentrated in Australia (1500 species) and South Africa (1300 species) with only 300 species found in other regions of the world [38]. The lipid rich elaiosome is a food source that attracts ants which transport the seeds back to their nest. Seeds are discarded after the elaisome is eaten, $S$. canadensis germination rates have been found to increase after elaiosome removal by ants [39]. This method of propagation may explain the patchy clumping of $S$. canadensis throughout its distribution and the genetic relatedness of local populations [37]. Introduced fire ants (Solenopsis invicta) pose a threat to bloodroot seed distribution. They significantly decrease native ant species [40] and in eating the elaisome they often damage the seed, depositing it in areas unsuited to germination. As the range of fire ants has extended, so has the threat to bloodroot [41,42].

After the flower has dehisced, the leaf reaches its full expansion, the plant having a height of $15-30 \mathrm{~cm}$. The leaf is palmate with seven to nine lobes and persists until August. Its upper surface is light green, while the undersurface is reticulated with prominent orange colored veins and has a grey down covering [43]. By the middle of summer, the aerial part of $S$. canadensis dies to the ground. Dormant plants can tolerate temperatures to $-20^{\circ} \mathrm{C}$ and are considered hardy [44]. 
Bloodroot grows best in light-to-medium well-drained soils and can tolerate a wide $\mathrm{pH}$ range, with optimal growth in soils of $\mathrm{pH} 5-7$ or higher [45]. Its favored position is open woods but it may also be found along fences and in tree fall clearings. S. canadensis grows more successfully in low C:N ratio soils as evidenced by increased leaf and flower numbers [46]. Conflicting reports exist on the effect of elevation on Bloodroot growth [46,47].

The rhizome of $S$. canadensis is reddish-brown externally, $2.5-10 \mathrm{~cm}$ in length and up to $4 \mathrm{~cm}$ in diameter. The rhizome is truncated with abrupt ends and covered with orange-red colored rootlets [43]. When cut, S. canadensis rhizomes exude a thick red latex that contains a number of alkaloids. These bioactive defense chemicals help to protect the plant from micro-organism, insect and herbivore predation [11].

\section{Historical Uses of S. canadensis}

Historical uses of herbs can provide valuable information for the research and development of new therapies. S. canadensis has been extensively used to treat a number of symptoms and conditions by Native Americans and European colonists [48]. Adverse effects however were also recognized, suggesting the herbs therapeutic or toxic action may be strictly dose-dependent.

\subsection{Traditional Native American Uses of S. canadensis}

Native American people, especially of the Algonquian, Iroquois and Siouan language groups, developed a range of uses for S. canadensis [49], which they called poughkone or puccoon. It was highly valued as a skin dye when mixed with walnut oil or bear's grease [50] and was attributed with magical properties by Poncan bachelors, who used it as a love charm [51]. It was also used as a traditional medicine to treat a variety of symptoms and conditions.

Several tribes used bloodroot to treat colds and congestion as either a tea or an inhaled powder [52]. The Ojibwe of Wisconsin used bloodroot as a lozenge for sore throats by adding it to a cube of maple sugar [53]. It was also used to treat diphtheria [54] and cases of haemorrhagic tuberculosis [52] where a small piece of bloodroot was added to concoctions, as larger doses would cause poisoning.

S. canadensis also had gastrointestinal effects with some tribes using small doses to stop vomiting [55] while other tribes used larger doses as an emetic [56]. It was made into a tea with blue cohosh to treat abdominal cramps [57] and was used to treat gastrointestinal haemorrhages and abdominal lumps [52]. Two tribes used bloodroot to treat haemorrhoids with the Malechite Indians heating the rhizome in a small kettle which was used when steaming [58] and the Cherokee using a bloodroot dampened cloth for manual reduction [52].

Native American women used bloodroot when having menstrual difficulties [52] and also used it as an abortificant [59]. The elderly used it as a tea to help their rheumatism while the Rappahannocks used it to purge fever [60].

S. canadensis was extensively used as a topical therapy by many tribes. Rhizomes were boiled in 1-2 liters of water, the liquid cooled to body temperature and applied as a coagulant to axe wounds [52]. Rhizomes were also applied to wounds as a poultice, while the Meskwaki would chew the roots and apply the masticated spittle to relieve the pain of burns [61]. The antibacterial properties of bloodroot were known to Native Americans who used it to treat wound infections [62] and gangrene [58]. The dry powdered rhizome was also used as an escharotic [63].

\subsection{Early Western Use of S. canadensis}

European colonists, through their interaction with Native American peoples, learned of the medicinal value of $S$. canadensis. Medical practitioners began using bloodroot for the treatment of Western illnesses [64]. During their investigations, the rhizome was confirmed as being of medical benefit while the leaves and seeds of the plant induced tremors, headache and torpor described as a stupefying or narcotic effect [65]. 
Respiratory uses of bloodroot rhizomes include as a bronchial muscle relaxant for asthma [66], a treatment for croup [67], influenza and whooping cough [68], an expectorant at a dose of one to two grains (one grain is equivalent to $64.5 \mathrm{mg}$ ) every second hour [43], an antibacterial agent to treat diphtheria and pneumonia [69], a treatment for tuberculosis [66] and as an inhaled powder to treat nasal polyps [70].

Bloodroot was also used to stimulate appetite [71], treat dysentery [72], functional dyspepsia [73], jaundice and chronic liver disease [74] and as a cure for alcoholism [75]. The administration of twenty grains (about $1.29 \mathrm{~g}$ ) was used as an emetic [76]. It was also used as an emmenagogue to restore menses [77]. Bloodroot was also used to treat rheumatism suggesting anti-inflammatory properties [78].

During this period, an expanding range of topical applications was developed. A tincture made of bloodroot, rose water and vinegar was applied as a wash for eczema, ringworm and facial pimples. With the addition of glycerine it was used to rejuvenate hair follicles and prevent baldness [79]. A Sanguinaria nitrate ointment was employed for treating indolent ulcerative conditions of the skin, throat and anal fissures [79] while for syphilitic chancres it was used in a powdered form [80].

An American surgeon, Jesse Weldon Fell, learnt of the Cherokee Indians use of bloodroot to treat cancer, and found that zinc chloride enhanced its action [81]. Fell pioneered the combination of these two agents into a cancer salve first reported in the medical literature in the Lancet in 1857 [82]. Similar topical treatments known as Black Salve remain in use today.

\section{Phytochemicals in S. canadensis}

With its history of ethnobotanical use and apparent multi-system activity, S. canadensis has been studied to identify its active constituents as potential pharmaceutical agents. Most of this work has focused on the alkaloids contained within the rhizome, although long chain alcohols (C26-C34), phytosterols and triterpines have also been detected in the plant [83]. With bloodroot currently used for livestock and human therapeutic applications, it is important to understand the bioactive alkaloids it contains. As compound concentrations likely impact on product efficacy and toxicity, an understanding of factors that influence alkaloid levels in the plant is also of clinical relevance.

\subsection{Identification of Alkaloids in S. canadensis}

In 1827, Dana isolated a copper red extract from S. canadensis that was named sanguinarine [84]. Several years later in 1839 a different extract was isolated and named chelerythrine [85]. However, both these compounds were actually collections of alkaloids, with pure chelerythrine not being isolated until 1893 [86], and pure sanguinarine not being isolated until 1924 [87]. Sanguinarine and chelerythrine are the major quaternary benzophenanthridine alkaloids (major QBA) present in S. canadensis.

Following the development of column chromatography in the 1950s, a number of new benzophenanthridine alkaloids were discovered in S. canadensis. Being present in lower concentrations, they are termed the minor quaternary benzophenanthridine alkaloids (minor QBA). Chelirubine and chelilutine were first isolated from Chelidonium majus constituting $0.013 \%$ and $0.002 \%$ of its alkaloids (Slavik, 1954). They have also been obtained from a number of Papaveraceae species with S. canadensis rhizomes, to date, having the highest content of these minor QBAs at $0.074 \%$ and $0.229 \%$ respectively [4,88]. Sanguilutine and sanguirubine were isolated in 1960 from S. canadensis [4]. In an analysis of six plant species known for their alkaloid content, these minor alkaloids were only detected in S. canadensis [89].

\subsection{Alkaloid Distribution in Different Plant Tissues of S. canadensis}

The distribution of sanguinarine in different S. canadensis tissues is shown in Figure 2 [90]. Sanguinarine has its greatest concentration in the plants rhizome, followed by the roots, with minimal concentrations present in the leaves and flowers. The distribution of other alkaloids within S. canadensis is currently not documented. 


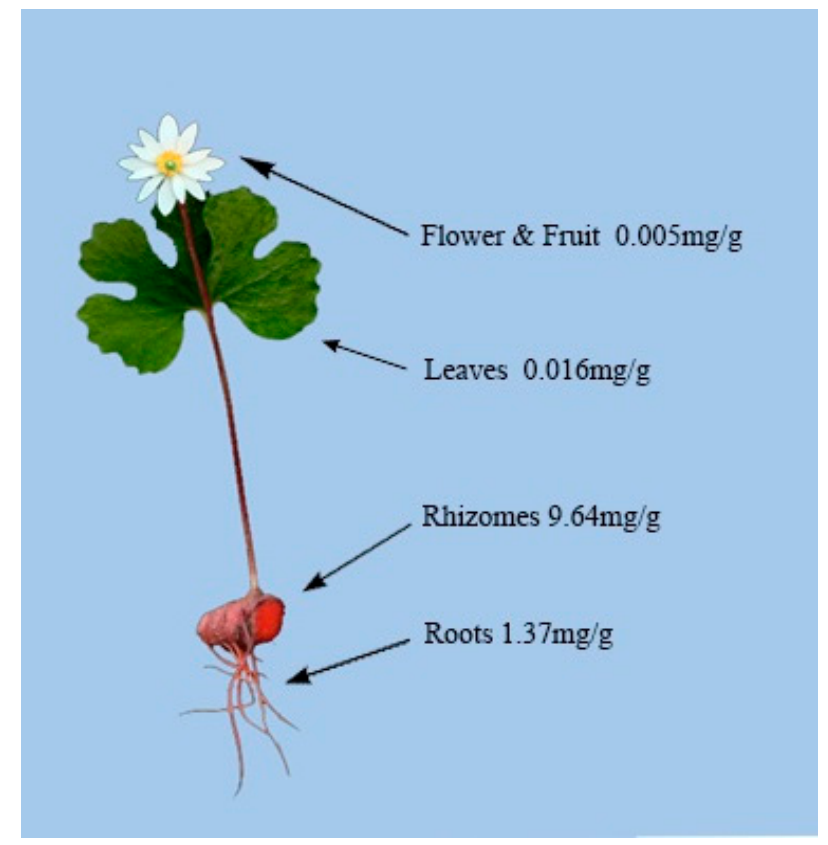

Figure 2. Average annual Sanguinarine concentrations in S. canadensis [90].

\subsection{Rhizome Alkaloid Composition and Variation}

The first exhaustive phytochemical study of $S$. canadensis rhizomes was performed by Slavik and Slavikova of Masaryk University Czechoslovakia in 1960 using a pseudocyanide isolation technique and column chromatography [4]. They imported undamaged rhizomes from a Chicago firm in the United States. S. canadensis rhizomes were found to contain an alkaloid pool consisting of the major QBAs sanguinarine (36.5\%) and chelerythrine (33.4\%), and the minor QBAs sanguilutine $(9.1 \%)$, chelilutine $(7.8 \%)$, chelirubine $(2.5 \%)$ and sanguirubine $(1.2 \%)$ [4]. In addition, the protopin alkaloids protopine $(4.1 \%)$ and allocryptopine $(4.2 \%)$ and trace amounts of the protoberberine alkaloids berberine and coptisine $0.1 \%$ were also identified [4].

Subsequent studies analyzing rhizome alkaloid composition in wild US populations have shown considerable natural alkaloid variation. The largest study assessed $100 \mathrm{~S}$. canadensis populations over a range extending from North Carolina to Vermont, and west to Indiana. Plants were sampled when flowering, fruiting, post fruiting and prior to leaf senescence with 10-40 plants collected from each site [21]. Sanguinarine was found to contribute over $50 \%$ to the $S$. canadensis alkaloid pool with rhizome dry weight concentrations varying from $0.6 \%$ to $6.3 \%$ (average of $2.7 \%$ ) [21]. Confirming earlier work [91,92], rhizome sanguinarine levels displayed a seasonal variation being maximal during flowering and early fruiting. The presence and concentration of alkaloids other than sanguinarine were not reported by the authors.

Cheleryrthrine, the other major QBA found in S. canadensis, also displays seasonal concentration variations in wild populations, being lowest during the Northern hemisphere summer months between July and September [93]. Comparing wild to cultivated bloodroot populations, rhizomes collected from May to November showed similar alkaloid concentrations. However, this collection time occurred outside the period of anthesis and early fruiting when wild alkaloid rhizome content is maximal.

Another study included the minor QBAs in its alkaloid rhizome analysis. Rhizomes were collected from 42 sites along an elevational transect between Athens, Georgia and Franklin, North Carolina. Bloodroot samples were collected when plants were in dormancy and at late seed set, both periods associated with low rhizome alkaloid concentrations. They found higher minor QBA and protopin alkaloid levels compared to those reported by Slavik. The alkaloid pool consisted of sanguinarine $30.4 \%$, chelerythrine $18.8 \%$, sanguilutine $12 \%$, chelilutine $11.3 \%$, chelirubine $9.5 \%$, sanguirubine $0 \%$, 
protopine $9.5 \%$ and allocryptopine $8.4 \%$ [20]. Lacking minor QBA standards, study data potentially relating to sanguirubine was excluded due to the coelution of sanguirubine and berberine high performance liquid chromatography (HPLC) peaks.

Several studies that assessed seasonal rhizome alkaloid variation in wild S. canadensis showed that the current understanding of $S$. canadensis alkaloid composition is incomplete $[21,94,95]$. This is especially the case for chelerythrine, the minor QBA and protopin alkaloids around anthesis when alkaloid concentrations are likely maximal [21,94,95].

Individual S. canadensis populations can also have significant alkaloid profile variations, with a $18.7 \mathrm{mg} / \mathrm{g}$ chelirubine yield (five times higher than the samples major QBA chelerythrine level) [94], or a $9 \%$ sanguinarine level, three times above the average rhizome content [21]. As bloodroot has been used as a base ingredient for livestock and human applications, levels of individual alkaloid exposure may be difficult to predict.

\subsection{Other Factors Affecting S. canadensis Rhizome Alkaloid Concentrations}

Both environmental and genetic factors may affect $S$. canadensis alkaloid production. The concentration of some bloodroot alkaloids, especially the majority of the benzophenanthridine alkaloids, appears to significantly depend on clonal genetics with an up to 10-fold concentration variance being attributed to clone. This genetic influence was not however universal, with chelirubine and protopin alkaloid concentrations found to be unrelated to clone [20].

Pressures on plant populations by pathogens and herbivores are known to increase with decreasing latitude $[96,97]$. Not surprisingly, there are increasing rates of alkaloid-bearing plants and an increase in the concentration of those alkaloids with decreasing latitude [98]. S. canadensis alkaloid concentrations were found to significantly reduce above 40 degrees latitude north of the Pennsylvania-West Virginia border [21].

Herbivory also often declines with increasing elevation reducing the need for costly resource consuming alkaloid chemical defenses $[99,100]$. Elevation also has an effect on S. canadensis alkaloid production with all QBA and protopin type alkaloid concentrations reducing with increasing elevation except for chelerythrine [47].

Cultivated rhizomes are often slightly larger than wild crafted bloodroot but have lower alkaloid content, perhaps due to a reduced need for chemical defenses. Cultivated rhizomes do not display seasonal alkaloid variation like their wild rhizome counterparts [93].

Plant maturity has been shown in Macleaya macrocarpa, a member of the Papaveraceae, to result in 3 to 14-fold higher rhizome minor QBA concentrations when comparing 12 year old plants to 2 year old plants [101]. S. canadensis requires $4-5$ years of growth to reach a harvestable size, with older plants similarly being found to have higher alkaloid concentrations [94].

Soil properties such as the carbon to nitrogen ratio have also been shown to affect $S$. canadensis growth, although the impact on alkaloid production has yet to be assessed [46]. While high fertilizer exposure has been shown to reduce alkaloid concentrations [20]. This may be due to a shift from defense to growth [45], an artefact from increased alkaloid vacuole volume or reduced alkaloid production due to root nutrient burn.

Increasing shade has been shown to increase the benzophenanthridine and protopin alkaloid concentrations in S. canadensis [20]. Benzophenanthridine alkaloids are photoreactive toxins that could result in autotoxic events when in high ambient light environments [102]. Plants in reduced shade may therefore lower their alkaloid concentration to reduce the risk of autotoxicity.

\section{Biological Activities of S. canadensis Alkaloids}

Alkaloids, as a chemical class, have been successfully developed into valuable therapeutics, while a number are also recognized as potent toxins and poisons. Some alkaloids may act as a medicine or a poison depending on their dose of administration. An understanding of the molecular effects of S. canadensis and its bioactive molecules is necessary to fully assess its therapeutic potential and toxicity. 


\subsection{Anti-Cancer Effects of S. canadensis Alkaloids}

\subsubsection{Sanguinarine}

Sanguinarine $\left(\mathrm{C}_{20} \mathrm{H}_{14} \mathrm{NO}_{4}\right)$ is the most studied alkaloid of $S$. canadensis, existing in either a charged iminium (pH 2-6) or uncharged alkanolamine (pH 6.5-9.0) form [103,104]. While both forms exist at physiological $\mathrm{pH}$ [105], the alkanolamine form is more lipophilic, having a greater penetration and cellular availability [106]. The iminium form is biologically active with spectroscopic studies revealing it to be the form that binds to nucleic acids. High concentrations of nucleic acids cause an equilibrium shift that transforms alkanolamine to the charged iminium form [107]. Sanguinarine is thus able to move into cells and accumulate in the nucleus and nucleic acid rich organelles, where it is activated to exert its cellular effects [108].

Sanguinarine interacts with DNA via intercalation, having a binding co-efficient comparable to the anthracycline agents daunorubicin and doxorubicin [109-111]. Its binding impairs DNA polymerase inducing DNA strand breaks and cell death [11,112]. It also prevents DNA strand break reconnection through depletion of nuclear topoisomerase II [113,114], this enzyme being the target of the chemotherapy drug etoposide [115].

Sanguinarine binds and caps telomeres inducing rapid apoptosis [116,117]. It also binds G-Quadruplex oncogenes c-Myc, KRAS and C-kit resulting in cell cycle termination [118-120]. In addition, it has been found to target the cellular cytoskeleton, inducing irreversible microtubule depolymerization [121] which inhibits cell proliferation inducing cell death [122].

Triple Helix H-DNA is present in c-Myc and Bcl-2 haematological malignancies $[123,124]$ and is associated with poorer outcomes in colorectal cancer patients [125]. Sanguinarine binds to and impairs H-DNA [126,127]. Sanguinarine also inhibits B-DNA to Z-DNA transition altering DNA supercoiling [128,129]. This in combination with its binding to core histones results in altered chromatin structure and gene expression [130,131].

Through its direct genetic and epigenetic effects, sanguinarine has been shown to alter gene expression in HeLa cells [130]. Exposure to a non-cytotoxic $2 \mu \mathrm{M}$ sanguinarine concentration resulted in the down regulation of 378 genes, mostly involved in metabolic pathways. A total of 348 genes involved in cell signaling, cell adhesion, extracellular matrix (ECM) receptor interaction and complement coagulation cascades were also upregulated at this concentration. When increased to a $5 \mu \mathrm{M}$ concentration, a significant number of apoptosis genes such as DIABLO (direct inhibitor of apoptosis binding protein with low isoelectric point) were activated, with 225 genes being upregulated and only 35 genes being downregulated [130].

Sanguinarine also interacts with a variety of RNA molecules. It strongly intercalates with messenger RNA (mRNA) poly (A) inducing self-structure formation disrupting poly (A) polymerase (PAP) transcription [132]. Each molecule of sanguinarine binds six transfer RNA (tRNA) base pairs by intercalation further interfering with protein synthesis. Sanguinarine also strongly binds double stranded RNA (dsRNA) that are involved in gene silencing and epigenetic regulation [133].

Sanguinarine additionally impacts on protein transcription as shown by the proteomic analysis of BxPC-3 pancreatic cancer cells when exposed to a $1 \mu \mathrm{M}$ concentration. Sanguinarine altered protein expression $>1.5$-fold in approximately $5 \%$ of 3107 identified proteins. A significant proportion of proteins affected by sanguinarine were involved in cellular metabolism with 61 proteins being upregulated and 87 downregulated [134]. This confirmed sanguinarine's pleotropic ability to effect a broad range of protein classes and target multiple critical cellular processes. Protein ubiquitination was the molecular pathway most affected by sanguinarine [134].

Apart from its direct action on cellular nucleic acids, sanguinarine exerts a cytotoxic effect in multiple cell lines via significant reactive oxygen species (ROS) generation [135]. Through redox cycling, apoptosis initiated by sanguinarine is p53 independent [136]. Conflicting results, however, regarding the role of ROS in sanguinarine's cytotoxic action have been reported. Some studies suggest ROS play a critical role while others have shown sanguinarine to inhibit oxidative bursts through a 
direct action on NADPH (Nicotinamide Adenine Dinucleotide Phosphate) oxidase rather than redox activity [137,138]. Further work is needed to clarify these conflicting actions.

When assessing sanguinarine's ROS anti-cancer effects in the SPCA1 human lung adenocarcinoma cell line, sanguinarine through ROS was found to induce endoplasmic reticulum (ER) stress [139]. ROS cause the unfolding and or misfolding of proteins that accumulate in the lumen of the ER [140]. This triggers a molecular cascade termed the unfolded protein response (UPR) [141]. Continuous ER stress promotes ROS formation creating a positive cytotoxic feedback loop [142]. For this reason, the UPR has been identified as an anti-cancer target [143].

Sanguinarine also causes a rapid and severe reduction in glutathione (GSH) levels. Although glutathione is an antioxidant, this depletion was due to a direct chemical action on GSH by sanguinarine, with $50 \%$ of cellular GSH being degraded within $1 \mathrm{~min}$ of exposure to a $5 \mu \mathrm{M}$ sanguinarine concentration [24]. Such significant GSH depletions can be apoptogenic in their own right [144,145]. This reduction in cellular antioxidant reserves accentuates the damage from sanguinarine induced ROS.

Tumor growth facilitated by neovascularization is another area targeted by sanguinarine [146,147]. At nanomolar concentrations, it inhibits vascular endothelial growth factor A (VEGF-A) induced endothelial cell migration, sprouting and survival $[148,149]$. Sanguinarine targets a range of cellular structures (Figure 3) and molecular processes. The contribution of each mechanism to the alkaloid's cytotoxicity and anticancer action is not clearly understood.
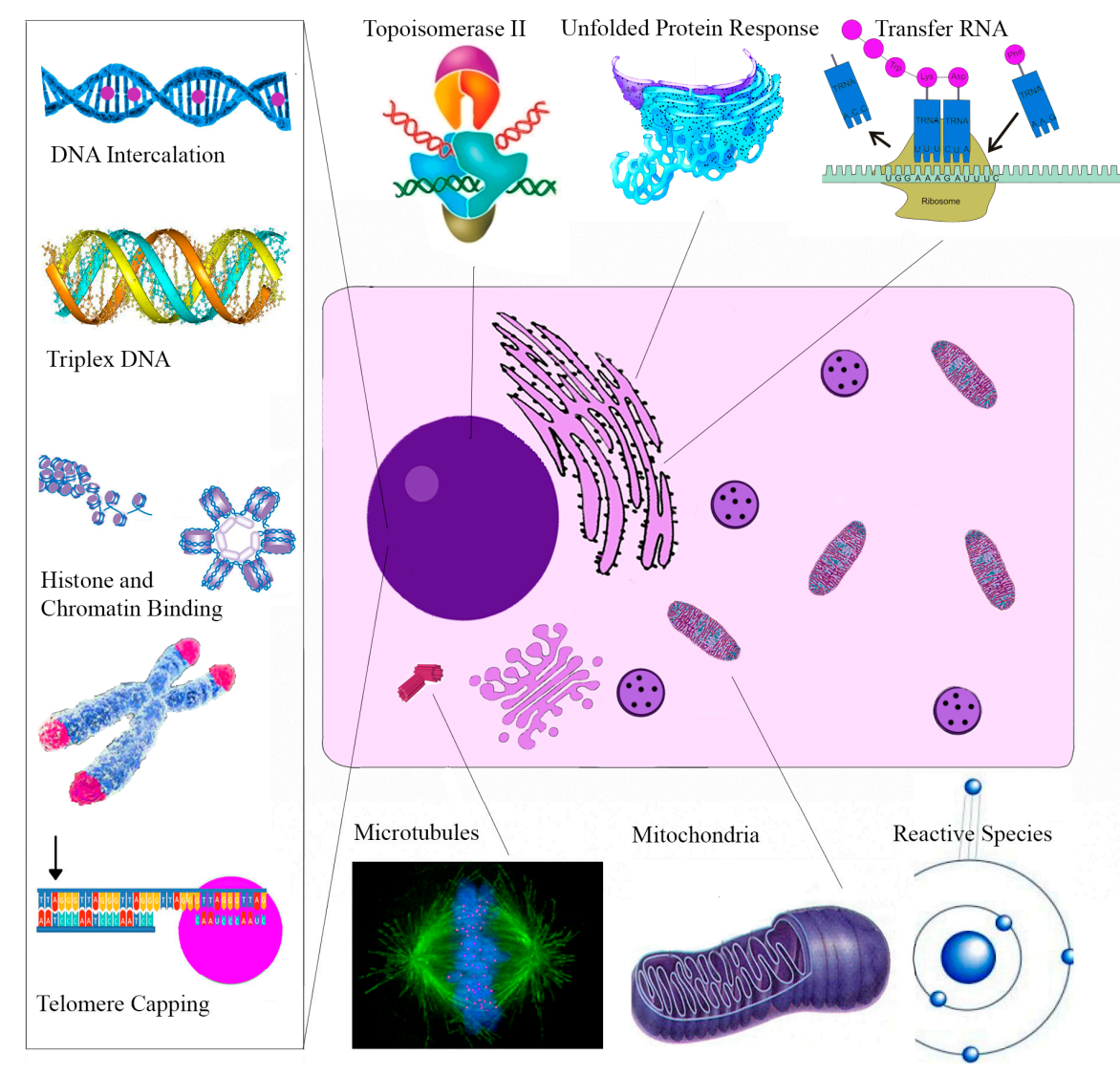

Figure 3. The cellular targets of sanguinarine. This figure highlights the variety of cellular organelles and molecular processes disrupted by sanguinarine. The only sanguinarine molecules (purple dots) in the diagram are represented in the DNA Intercalation image.

\subsubsection{Chelerythrine}

Chelerythrine is the second most prevalent alkaloid in S. canadensis having two methoxyl substituents at the $\mathrm{C} 11$ position on the aromatic $\mathrm{D}$ ring. Chelerythrine is less planar than sanguinarine 
and has a lower affinity for DNA [109]. Despite this, chelerythrine displays activity against a range of human tumors [150] including those that are radiotherapy, chemotherapy resistant [151] as well as p53-deficient [152,153].

Traditional high throughput drug discovery programs have identified chelerythrine as a lead oncology drug candidate. Of 107,243 extracts derived from plants, actinomycetes, fungi, marine invertebrates and marine bacteria, screened for their Bcl-XL and BH3 disrupting ability, 12 extracts had significant activity. Chelerythrine was the causative bioactive molecule in the four plant extracts with an $\left(\mathrm{IC}_{50}\right.$ of $\left.1.5 \mu \mathrm{M}\right)$ [153]. A further study that screened 6700 compounds for mammalian target of rapamycin (mTOR) inhibitors found chelerythrine had the greatest cytocidal action against cells with mTOR hyperactivity [154].

\subsubsection{Minor Quaternary Benzophenanthridine Alkaloids (QBAs)}

Less is known about the biological activities of the minor QBAs, which are generally present in lower concentrations in S. canadensis. Sanguilutine has greater cytotoxicity than the major QBAs with lower $50 \%$ inhibitory concentrations $\left(\mathrm{IC}_{50}\right)[155,156]$. With $\mathrm{IC}_{50}$ values ranging from 0.04 to $1.58 \mu \mathrm{g} / \mathrm{mL}$, the minor QBAs are active at therapeutically relevant doses (Table 1).

Table 1. Comparison of the cytotoxicity of major and minor QBA $\left(\mathrm{IC}_{50}\right)[155,157]$.

\begin{tabular}{ccccc}
\hline Alkaloids $\left(\mathrm{IC}_{\mathbf{5 0}}, \boldsymbol{\mu g} / \mathrm{mL}\right)$ & HL-60 & HeLa & KF-II & A431 \\
\hline Sanguilutine & 0.04 & 0.46 & - & - \\
Sanguirubine & 0.12 & 0.68 & 0.22 & 0.7 \\
Chelilutine & 0.16 & 0.84 & - & - \\
Chelirubine & 0.1 & 0.37 & 0.2 & 0.28 \\
Sanguinarine & 0.34 & 0.7 & 0.5 & 0.7 \\
Chelerythrine & 0.17 & 0.48 & 0.58 & 1.44 \\
\hline
\end{tabular}

The minor QBAs appear to act through molecular processes that differ from the major QBAs. Chelilutine acts as a strong inducer of apoptosis without ROS generation [156], while sanguilutine induces melanoma cell death via necroptosis [158]. Necroptosis is a novel non-apoptotic caspase-independent programmed cell death facilitated by Receptor-interacting protein kinase 1 (RIP1) [159]. Sanguilutine activates RIP1 resulting in Ripoptosome (RIP1, FADD and caspase-8) formation leading to cell death [158]. Cancer cells are often resistant to therapies due to altered apoptotic machinery. Compounds like sanguilutine that act by alternate pathways are of growing interest.

\subsubsection{Protopin Alkaloids}

Unlike the benzophenanthridines, protopin alkaloids have minimal antiproliferative effects on a range of cancer cell lines (Sun et al., 2014). Protopine alleviates oxidative stress and apoptosis, partially by antioxidant mechanisms and $\mathrm{Ca}^{2+}$ antagonism [160]. Protopine may therefore antagonize the cytotoxic action of other S. canadensis alkaloids. Protopine has been found to impair the cancer cell invasion and metastatic potential of MDA-MB-231 breast cancer cells by reducing the expression of adhesion molecules such as epidermal growth factor receptor (EGFR), ICAM-1 and integrins [161].

Although having a similar chemical structure, the alkaloids present in S. canadensis have many unique molecular specificities (Table 2). Sanguinarine, for example, is a potent inhibitor of NF- $k B$, while chelerythrine lacks NF- $\mathrm{kB}$ activity [162]. When bloodroot alkaloids share a molecular target, they may bind different sites on the molecule, as is the case with the pro-survival protein Bcl-XL [163]. The impact of simultaneous target exposure to different alkaloids has not been extensively studied. Whether alkaloids would antagonize or augment target disruption is an unresolved question of direct clinical relevance. 
Table 2. Anticancer Effects of S. canadensis alkaloids.

\begin{tabular}{|c|c|c|}
\hline Molecular Target & Cellular Effect/Significance & Ref. \\
\hline \multicolumn{3}{|c|}{ Sanguinarine } \\
\hline Topoisomerase II & Prevents DNA break repair & [114] \\
\hline Telomere Capping & Induces rapid apoptosis & [164] \\
\hline Oncogenes C-myc, KRAS, C-kit & Expressed in various tumors & [120] \\
\hline H-DNA & Haematological and colorectal tumor expression & [127] \\
\hline Bcl-2 family & Apoptosis induction & [165] \\
\hline ERKs & Apoptosis induction & [166] \\
\hline NF- $k B$ & Role in proliferation, migration, apoptosis & [162] \\
\hline DR-5 & TRAIL mediated apoptosis & [167] \\
\hline Endoplasmic Reticulum & Unfolded Protein Response & [139] \\
\hline VEGF-A & Impairs tumor neovascularization & [148] \\
\hline Glutathione & Depletion amplifies oxidative stress & {$[24]$} \\
\hline Anti-microtubule & Inhibits cell proliferation & [121] \\
\hline \multicolumn{3}{|c|}{ Chelerythrine } \\
\hline $\mathrm{Bcl}-\mathrm{XL}$ and $\mathrm{Bcl}-2$ & Apoptosis Induction & [153] \\
\hline Telomere Capping & Induces rapid apoptosis & [168] \\
\hline Succinate & Cytochrome c release & [169] \\
\hline NADH dehydrogenase & Apoptosome assembly & [169] \\
\hline Glutaminase & Blocks Tumor Glutamine use for energy & [170] \\
\hline mTOR & Overexpressed in Melanoma & [154] \\
\hline Phospholipase D & Associated with angiogenesis/metastasis & [171] \\
\hline MRCK & Impairs tumor migration & [172] \\
\hline Tubulin Polymerization & Impairs cell division & [122] \\
\hline MAPK & Activation results in apoptosis & [173] \\
\hline \multicolumn{3}{|c|}{ Minor QBAs } \\
\hline RIP1 & Ripoptosome Formation & [158] \\
\hline Unknown & Apoptosis ROS independent & [156] \\
\hline Anti-microtubule & Impaired mitosis & [174] \\
\hline \multicolumn{3}{|c|}{ Protopin Alkaloids } \\
\hline Antioxidant effect & May antagonize the cytotoxic effects of other alkaloids & [175] \\
\hline EGFR/ICAM-1 & Reduced expression impairs metastasis & [161] \\
\hline
\end{tabular}

\subsection{Cardiovascular Effects of S. canadensis Alkaloids}

Sanguinarine has been found to have a vasodilatory effect, inhibiting $\alpha-1$ and $\alpha-2$ adrenoceptors with an $\mathrm{IC}_{50}$ of 33.6 and $6.4 \mu \mathrm{M}$, respectively [176]. When investigating 19 Panamanian plants used as traditional medicines to treat hypertension, the extract of Bocconia frutescens L. containing sanguinarine [177], inhibited angiotensin II binding by 50\% [178]. Sanguinarine has been shown to block angiotensin II in a slow, nearly irreversible and non-competitive manner [179]. In addition, protopine has vasodilator effects by elevating cAMP and cGMP [180].

Several bloodroot alkaloids interact with cardiac ion channels. Sanguinarine has been found to inhibit $\mathrm{Na}^{+}-\mathrm{K}^{+}$ATPase activity, similar to the pharmaceutical digoxin, with an $\mathrm{IC}_{50}$ of $6.0-6.5 \mu \mathrm{M}$. In guinea pig atria this elevates intracellular $\mathrm{Na}^{+}$, activating the $\mathrm{Na}^{+} / \mathrm{Ca}^{2+}$ exchanger resulting in increased intracellular $\mathrm{Ca}^{2+}$ levels, a $10 \mu \mathrm{M}$ dose having a positive inotropic effect [181]. Protopine acts as a promiscuous cation channel inhibitor in guinea pigs blocking $\mathrm{Ca}^{2+}, \mathrm{K}^{+}$and $\mathrm{Na}^{+}$ion channels [182], while allocryptopine blocks $\mathrm{K}^{+}$channels in rabbit ventricular myocytes [183]. Allocryptopine is more effective than quinidine in preventing induced arrhythmias in rats [184]. Chelerythrine in cultured neonatal rat cardiac myocytes induces apoptotic death at a concentration of $6-30 \mu \mathrm{M}$ due to the generation of ROS [185]. 


\subsection{Anti-Inflammatory Actions of S. canadensis Alkaloids}

Inflammation is induced by pro-inflammatory enzymes such as COX-2, NO and PGE2 and the inflammatory cytokines TNF- $\alpha$, Interleukin IL1 and IL6. Protopine exerts an anti-inflammatory action being a potent NO inhibitor, reduces COX-2 expression and impairs the production of PGE2, IL-1B, IL- 6 and TNF- $\alpha$. This occurs through the inhibition of ERK $1 / 2$ and JNK phosphorylation and NF- $\mathrm{KB}$ activation in murine macrophages [186]. Protopine has been found to inhibit carrageenan-induced rat paw oedema with a potency three-fold higher than acetylsalicylic acid [12].

Chelerythrine has also been found to exert an anti-inflammatory action by inhibiting COX-2 and PGE2 production [187]. The inhibitory COX-2 potency of chelerythrine is comparable to NS-398 a specific Cox-2 inhibitor. Chelerythrine also has an effect on 5-lipoxygenase inhibition [188] and oxidative burst attenuation $[189,190]$.

Polymorphonuclear leukocytes (PMN) release cytokines and lytic enzymes that fuel inflammation, however, when PMN undergo apoptosis, they are removed by the reticuloendothelial system without inflammatory mediator release [191]. PMN apoptosis has been found to be a major mechanism of inflammation resolution in the gut, lung, joint and kidney [192-194]. Chelerythrine induces rapid apoptosis in human PMN via a PKC (Protein Kinase C) independent mechanism preceded by rapid caspase- 3 activation. $10 \mu \mathrm{M}$ chelerythrine chloride induces rapid and significant PMN apoptosis in less than $4 \mathrm{~h}$ [195].

Intercellular adhesion molecules (ICAM) and vascular cell adhesion molecules (VCAM) facilitate the migration of neutrophils into tissues [196] and are key components of inflammatory disease processes such as asthma $[197,198]$ and inflammatory arthritis $[199,200]$. Testing of 40 natural and synthetic alkaloids, terpenoids and phenolics found sanguinarine and isoliquiritigenin significantly downregulated VCAM-1. Of the 10 compounds that downregulated ICAM-1, sanguinarine had the greatest effect, reducing expression by $50.6 \%$ [201].

\subsection{Anti-Infectious Effects of S. canadensis Alkaloids}

As a group, the benzophenanthridine and protopin alkaloids of $S$. canadensis have significant antimicrobial action. Sanguinarine has been found to induce the release of bacterial membrane-bound cell wall autolytic enzymes resulting in activity against Methicillin-Resistant Staphylococcus Aureus (MRSA) with a minimum inhibitory concentration (MIC) for two reference strains of $1.56 \mu \mathrm{g} / \mathrm{mL}$ and $3.12 \mu \mathrm{g} / \mathrm{mL}$ [202]. Sanguinarine has bactericidal activity against gram negative and gram positive vancomycin resistant organisms, when co-administered sanguinarine rendered the organisms vancomycin sensitive [203]. When tested against 64 different oral microbial species, sanguinarine's MIC ranged from 1 to $16 \mu \mathrm{g} / \mathrm{mL}$ for $98 \%$ of isolates [204].

Helicobacter pylori has a pathogenic role in gastritis and peptic ulcer disease with increasing resistance rates to current combination antibiotic therapies [205]. A methanol extract of $S$. canadensis rhizomes had an $\mathrm{MIC}_{50}$ against $H$. pylori of $12.5 \mu \mathrm{g} / \mathrm{mL}$ while individual alkaloids were less potent with $\mathrm{MIC}_{50}$ values of $50 \mu \mathrm{g} / \mathrm{mL}$ for sanguinarine and $100 \mu \mathrm{g} / \mathrm{mL}$ for chelerythrine and protopine [206], suggesting the alkaloids may have a synergistic effect.

On testing 43 plant species traditionally used for treating tuberculosis, extracts of $S$. canadensis were shown to have antimycobacterial activity. On analyzing the activity of individual constituents, chelerythrine was found to be the most active with an $\mathrm{IC}_{50}$ of $7.3 \mu \mathrm{g} / \mathrm{mL}(19.02 \mu \mathrm{M})$ against Mycobacterium aurum with sanguinarine being the second most active with an $\mathrm{IC}_{50}$ of $9.61 \mu \mathrm{g} / \mathrm{mL}$ [207].

The alkaloids of $S$. canadensis also appear to have anthelmintic activity. Schistosomiasis is a snail-borne parasitic disease which affects over 200 million people worldwide, and is usually treated with Praziquantel [208]. New therapies are required as Praziquantel does not treat early infection (Magnussen, 2003) and schistosome resistance has been reported in endemic areas such as Egypt [209]. On testing 45 compounds, sanguinarine was one of two compounds where a $10 \mu \mathrm{M}$ concentration resulted in 100\% parasite mortality after $48 \mathrm{~h}$, meeting the World Health Organisation's compound "hit" criteria [210]. 
Strongyloides stercoralis is a parasitic infection affecting 100 million people in tropical zones worldwide [211]. Cure rates for current anthelmintics range from $84 \%$ for Ivermectin to $46 \%$ for Albendazole [212]. Protopine and allocryptopine have been demonstrated to show significant activity with average $50 \%$ larval paralysis concentrations of 42.5 and $66 \mu \mathrm{M}$, respectively (Satou, Koga, et al., 2002), with protopine's ratio of parasite to human cell toxicity being superior to that of Ivermectin and Albendazole [213].

Parasitic infestation is an increasing issue in aquaculture, with freshwater fish at risk of gill monogenean infestation, especially Dactylogyrus [214]. Sanguinarine was found to have the greatest potency of Macleaya microcarpa (Maxim) Fedde aerial alkaloids with an $\mathrm{EC}_{50}$ of $0.37 \mathrm{mg} / \mathrm{L}$. Less potent actions were recorded for 6-methoxyl-dihydro-chelerythrine $3.63 \mathrm{mg} / \mathrm{L}$, allocryptopine $4.64 \mathrm{mg} / \mathrm{L}$ and protopine $8.13 \mathrm{mg} / \mathrm{L}$ [215].

Veterinary anthelmintic applications have been explored with alkaloids tested against dog roundworm Toxocara canis. Few anthelmintics are effective against nematodes and then often only when they are present in the gastrointestinal tract. Pyrantel pamoate has a relative mobility $50 \%\left(\mathrm{RM}_{50}\right)$ inhibition against intestinal Toxocara canis at a concentration of $46 \mu \mathrm{mol} / \mathrm{L}$. Strong nematocidal activity has been observed for 6-methoxydihydrosanguinarine $\mathrm{RM}_{50} 18 \mu \mathrm{mol} / \mathrm{L}$, chelerythrine $\mathrm{RM}_{50} 28 \mu \mathrm{mol} / \mathrm{L}$ and sanguinarine $58 \mu \mathrm{mol} / \mathrm{L}$ [216]. The authors argued that due to the HL60 cytotoxicity of these agents with $\mathrm{IC}_{50}$ values for 6-methoxydihydrosanguinarine of $0.3 \mu \mathrm{mol} / \mathrm{L}$, chelerythrine $0.2 \mu \mathrm{mol} / \mathrm{L}$ and sanguinarine $0.5 \mu \mathrm{mol} / \mathrm{L}$, other compounds would be better therapeutic candidates. However, the HL60 cell line chosen to determine alkaloid cellular toxicity, is more sensitive to alkaloid damage than non-malignant cells and may overestimate the potential toxicity risk [138]. Allocryptopine, had a $\mathrm{RM}_{50}$ of $349 \mu \mathrm{mol} / \mathrm{L}$ and an $\mathrm{IC}_{50}$ of $48 \mu \mathrm{mol} / \mathrm{L}$, its lower $\mathrm{RM}_{50} / \mathrm{IC}_{50}$ resulted in its recommendation as a more promising compound for pharmaceutical development [216].

A screening study of 2000 drugs and natural products found sanguinarine had antiviral activity inhibiting HIV protease with an $\mathrm{IC}_{50}$ of $13 \mu \mathrm{M}$ [217]. Sanguinarine also has activity against herpes simplex virus while protopine and allocryptopine are both active against Parainfluenza Virus-3 [218].

Protopine displays promising anti-plasmodial activity against TM4 wild type and multi-drug resistant (K1) P. falciparum strains with an $\mathrm{IC}_{50}$ value of $1.5 \mu \mathrm{g} / \mathrm{mL}$ [219]. Chelerythrine and sanguinarine were found to be especially active against the trypanosome T. brucei the cause of sleeping sickness with $\mathrm{EC}_{50}$ of 1.3 and $4.8 \mu \mathrm{M}$, respectively [220]. While the antifungal activity of protopine is uncertain, one study suggested minimal activity [221] while another showed strong inhibition of Candida albicans with a $4 \mu \mathrm{g} / \mathrm{mL}$ exposure [218].

\subsection{Other Biological Activities of S. canadensis Alkaloids}

There are also reports of the S. canadensis alkaloids having neurotransmitter, local anesthetic, gastrointestinal and coagulation effects. Plant alkaloids have provided acetylcholinesterase inhibitor drug leads for the treatment of Alzheimer's disease; for example, galanthamine derived from Galanthus woronowii and Rivastigmine, a semi-synthetic derivative of physostigmine from Physostigma venenosum, with both in clinical use [222]. In vitro and in vivo studies have identified both protopine and allocryptopine as potent acetylcholinesterase inhibitors [223,224]. While galanthamine has a $49 \%$ inhibitory action for acetylcholinesterase, allocryptopine and protopine cause greater inhibition of $89.31 \%$ and $80.53 \%$, respectively [225].

Chelerythrine has been investigated as a pharmacological agent to treat insulin resistance. In mice it more potently blocked peroxisome proliferator-activated receptor gamma (PPAR $\gamma$ ) phosphorylation than thiazolidinedione (TZD) drugs. Its transcriptional profile suggested to have reduced side effects compared to existing TZD medications [226].

Protopine also has potential uses as a neuroprotective agent in stroke and as an antidepressant. Protopine has been shown to reduce brain glutamate levels by $23 \%$ by increasing glutamate dehydrogenase (GDH) 1.6-fold [227]. Glutamate excitotoxicity and calcium overload are involved in the pathophysiology of stroke. Protopine appears to increase superoxide dismutase activity in serum 
suggesting its neuroprotective effect is partly related to its anti-oxidant properties. Protopine has also been suggested as a treatment for mood disorders as it seems to inhibit both the serotonin transporter (SERT) and noradrenalin transporter (NERT) [228]. Sanguinarine blocks nicotinic and 5-HT2 receptors with an $\mathrm{IC}_{50}$ of 11.8 and $91.7 \mu \mathrm{M}$, respectively [176].

A $1 \%$ solution of raw alkaloids from Macleaya cordata (Wild.) that has allocryptopine as its major alkaloid constituent has a local anesthetic effect [229]. A 1\% solution of these raw alkaloids has a stronger local anesthetic effect than procaine of similar concentration [230].

Allocryptopine appears to induce a relaxing effect on guinea-pig ileum via phosphodiesterase inhibition but has a contractile effect through its interaction with $\alpha$-adrenoreceptors on the bladder [231]. Protopine is a weak anticholinergic alkaloid that is 660 times less potent than atropine but still possesses an anti-spasmodic and relaxant effect on smooth muscle [232]. Sanguinarine blocks muscarinic receptors with an $\mathrm{IC}_{50}$ of $2.4 \mu \mathrm{M}$ [176].

Protopine also seems to act on platelets having a lower $\mathrm{IC}_{50}$ value against various platelet agonists such as arachidonic acid and platelet activating factor than those observed for aspirin [12]. While protopine selectively inhibits the synthesis of thromboxane A2, sanguinarine inhibits thromboxane B2 production [233].

\section{Current Uses of S. canadensis}

\subsection{Agriculture and Aquaculture Feed Supplement}

In 2006, the European Union ratified a ban prohibiting the use of antibiotics as animal growth supplements, due to increasing pathogen antibiotic resistance [234]. This has stimulated interest in phytogenic feed supplements that reduce gastrointestinal pathogen levels, enabling animals to redistribute immune defense resources to growth [235]. Thus, Sangrovit, derived from the aerial parts of M. cordata or the rhizomes of S. canadensis, was developed as a natural feed additive [236,237]. The sanguinarine content of Sangrovit was standardized to $1.5 \% w / w$.

In a number of studies, Sangrovit has been shown to improve weight gain in weaning pigs [238], broilers [239] and tilapia [240]. Sangrovit significantly reduced Salmonella enteritidis positive crop and cecal samples in broilers 7 days post Sangrovit inoculation [241]. Pigs fed diets containing $1.5 \mathrm{~g}$ of QBAs $/ 1000 \mathrm{~kg}$ of feed had more effective reduction in fecal Salmonella shedding than pigs administered chlortetracycline, a commonly used US feed antibiotic [242]. Sangrovit induced weight gain in fish appears due to appetite stimulation [240].

Due to toxicity concerns, Sangrovit 90 day feeding experiments at 50 times the recommended dose have been performed in rats and pigs. These did not show lymphocyte or hepatocyte genotoxic damage in rats [237], nor histological, haematological toxicity or DNA adduct formation in pigs despite plasma sanguinarine and chelerythrine levels reaching 0.11 and $0.2 \mu \mathrm{g} / \mathrm{mL}$, respectively [13]. This suggests the ingestion of $S$. canadensis alkaloid supplements over a period of months is not associated with toxicity.

\subsection{Veterinary Uses}

Bloodroot-containing topical therapies have been used to treat equine sarcoids. While locally invasive, these common horse tumors rarely metastasize but often recur after treatment [243]. In veterinary medicine, current bloodroot formulations include XXTERRA (Larson Labs, Fort Collins, CO, USA), Newmarket bloodroot ointment (Newmarket Premixes, Catley Cross, Halstead, UK) and Animex (Nies, Las Vegas, NV, USA). The composition of Newmarket bloodroot is $40 \% w / w 1: 3$ extract ( $25 \%$ methyl alcohol $/ 75 \%$ water) S. canadensis rhizome, $48 \% w / w$ emulsifying ointment, $10 \%$ zinc chloride and preservatives.

Small pilot studies have suggested equine sarcoid complete resolution rates comparable to Imiquimod [244,245]. With 57 owners reporting a 98\% complete resolution rate for smaller sarcoids $<2 \mathrm{~cm}$ diameter in a retrospective questionnaire [246]. Bloodroot products such as Neoplasene have 
also been used to treat tumors in dogs with a female Golden Retriever developing a fluctuant cutaneous mass following an intra-tumoral injection with subsequent post-operative complications [247].

\subsection{Dental Antibacterial Treatment}

The observed broad spectrum activity of $S$. canadensis alkaloids against oral micro-organisms led to the development of bloodroot based antiplaque and gingivitis therapies [204]. Viadent, a mouth rinse containing $0.3 \mathrm{mM}$ sanguinarine chloride, and a toothpaste containing $0.7 \mathrm{mM}$ sanguinarine chloride were offered as an alternative to chemical based oral antiseptics [248]. Viadent use, however, became associated with the development of leukoplakia, a pre-malignant condition, of the maxillary vestibule [249].

Although mouth rinsing is a brief activity of a few minutes duration, the maxillary vestibule has low salivary turnover and prolonged mucosal contact to rinse residue [250]. The safety of S. canadensis oral health care products had been assessed in a number of animal toxicity and human clinical efficacy studies [251], however, none of these studies were longer than 6 months' duration. Of patients with maxillary vestibule leukoplakia, $84 \%$ had used Viadent over an average of 4.4 years use [252]. Cessation of Viadent did not result in leukoplakia regression, suggesting permanent epithelial cell genetic alteration [253]. While Viadent did reduce dental plaque levels, it was inferior to Chlorhexidine as a treatment for gingivitis and gingival bleeding [254] and was withdrawn from sale in North America due to concerns about its carcinogenic potential.

\subsection{Homeopathic Treatment}

Hylands menopause treatment has been sold in the United States as an over the counter therapy for hot flushes for over 50 years. A homeopathic medicine, it contains $S$. canadensis $3 \times$ (1:1000 dilution), amyl nitrate $3 \times(1: 1000$ dilution) and Lachesis, the poison from the bushmaster snake $12 \times(1: 1,000,000,000,000$ dilution) [255]. One randomized clinical trial with 83 subjects has been reported in the literature with a Jadad score of 5 . Those using Hylands Menopause treatment had increased flush severity scores and developed headaches compared to the single compound remedy and placebo groups, suggesting a lack of efficacy for menopause [256].

An observational study of various homeopathic treatments in 438 patients with menopausal symptoms found $S$. canadensis remedies ranked fifth most likely out of 16 remedies to result in symptom disappearance or improvement. However, the study type and design prevented an assessment of efficacy [257].

Zeel comp. N (Zeel) is a homeopathic formulation derived from Sanguinaria canadensis, Arnica montana (Arnica), Solanum dulcamara (Climbing nightshade), Rhus toxicodendron (Poison Oak), and sulfur. Unlike classical homeopathic remedies, the therapy does not employ a single active ingredient and is not diluted "in extremis" having molar concentrations of $10^{-5}-10^{-12}$ [258].

A number of studies have been conducted in patients with osteoarthritis. One single blinded study compared intra-articular Zeel given twice weekly with intra-articular sodium hyaluronate given once weekly over a five-week period [259]. Another double blind randomized study in 121 patients compared oral diclofenac $25 \mathrm{mg}$ with oral Zeel, each tablet taken three times daily for 10 weeks [260]. The largest study, comparing Zeel tablets with COX-2 inhibitors, enrolled 592 patients in an open prospective multicenter reference controlled cohort study [261]. All of these studies reported equivalence between Zeel and conventional arthritis treatments.

\subsection{Use in Cancer Therapy}

\subsubsection{Mohs Paste}

In 1932, Frederick E. Mohs, while investigating the reaction of cancerous and normal tissues to various irritants, observed that a $20 \%$ solution of zinc chloride chemically killed tissues yet maintained their histologic structure [262]. Mohs believed that skin cancer recurrence occurred as a result of tumor 
cells present at the surgical margin escaping detection by standard histology procedures that only inspect $1 \%$ of an excised lesion [263].

Mohs developed a fixative paste that would histologically preserve human tissue in a controlled manner. In addition to zinc chloride, he found that stibnite and an extract from S. canadensis rhizomes stabilized the paste [264], allowing it to function like a reservoir that slowly released zinc chloride into surrounding tissues [265]. Mohs fixed tissue technique involves a thin layer of paste fixing the tumor in-situ, with a horizontal section taken through the base of the lesion $24 \mathrm{~h}$ later. The entire excision margin is then histologically assessed with any tumor involvement being mapped. Further fixative is then applied to these areas which undergo additional tissue removal. The process continues until histologically clear margins are achieved [266].

The technique became known as Mohs micrographic surgery. Using the fixed tissue method, Mohs 5 year cure rate for basal cell carcinoma (BCC) in 7257 cases was $99.3 \%$ and for squamous cell carcinoma (SCC) in 2551 cases was $94.4 \%$. This impressive result was achieved despite $20 \%$ of the patients having recurrent tumors following previous surgery or radiotherapy [267]. While S. canadensis is a component of Mohs paste, the high cure rates achieved by Mohs technique are attributable to the complete histological assessment of excision margins and not the anticancer action of S. canadensis, as demonstrated by the equivalent effectiveness of the later developed fresh tissue technique where margin controlled surgery is performed without a fixative paste [268].

\subsubsection{Salve Chemosurgery}

In the 19th century, the American surgeon Jesse Weldon Fell learned that Native Americans living on the shores of Lake Superior used S. canadensis rhizomes to treat cancer. Through experimentation he found its effectiveness could be enhanced by the addition of zinc chloride [269]. These constituents were mixed in equal parts with water forming the treacle-like Fells Paste.

Fells Paste was trialed in twenty five patients at Middlesex Hospital London in 1857, the majority of cases being breast cancer [82]. Fell also applied a brown bloodroot containing ointment to treat lymph node metastases and an internal S. canadensis therapy containing half a grain three times daily [81]. The Middlesex surgeons concluded zinc chloride was the only active constituent in the paste with bloodroot having no anticancer activity [270].

Fell reported in the Lancet that of 453 cancer patients he treated with the paste, many of these being advanced cases not suitable for surgery, the recurrence rate was $27.5 \%$ at two years. He argued this was a significant advance on the $80 \%$ recurrence rate achieved by surgery at two years [81]. The independently observed results from the 25 patients at Middlesex Hospital showed a 9 months recurrence rate of $21.4 \%$. This called into question the accuracy of Fells reported two year results. With $21.4 \%$ recurring by 9 months, it was not believed possible only $27.5 \%$ would recur by two years [270]. Unfortunately, two year recurrence rates for the Middlesex Hospital patients were not reported.

The provision of unproven bloodroot based oncology products to the public has not been an isolated event in medical history. In the early 20th century, another entrepreneur Harry Hoxsey [271], promoted a S. canadensis containing cancer therapy to the public. The Hoxsey cancer treatment utilized two external therapies, a yellow powder containing arsenic sulphide, sulphur, talc and yellow precipitate; also a red paste containing bloodroot, antimony trisulfide and zinc chloride [272]. Tonics were employed to treat internal malignancies but these did not contain S. canadensis [271]. There have been no clinical trials of the Hoxsey treatment. One observational study conducted from 1983 followed 39 cancer patients for 5 years. By the fifth year, $58.9 \%$ of patients had been lost to follow-up [273]. A pilot progressive cohort study of 149 patients, treated with the Hoxsey cancer treatment at the Tijuana Bio-Medical clinic, was conducted in 1992. Only $43.6 \%$ of records contained pathology reports with the 5 year vital status only assessable for $57 \%$ of patients. At 5 years, $11.4 \%$ of patients were alive, $45.6 \%$ had died and the outcome of $42.9 \%$ of patients was unknown [274]. These studies highlight the lack of scientific rigor employed by clinicians offering bloodroot oncology products and the unknown status of significant patient numbers, preventing an assessment of treatment efficacy. 
More recently, black salve, a S. canadensis containing topical cancer therapy, has been sold to patients especially through online vendors [275]. Formulations vary with one of the more established treatments known as Cansema or Amazon by Alpha Omega Laboratories containing zinc chloride, chapparal leaf extract (Larrea mexicata), graviola leaf extract (Annona muricata), oleander leaf extract (Nerium oleander), Bloodroot (S. canadensis) and glycerine [276]. The companies' internal cancer tonic Cansema (Amazon) Tonic III does not list bloodroot as an ingredient. There are no recorded clinical trials of black salve despite vendor claims of better than $98 \%$ skin cancer success rates [276] with minimal adverse reactions [276]. Some vendors suggest black salve can be used to treat melanoma [276,277].

There are significant concerns about the effectiveness of black salves. Cases of extensive tissue destruction [278] and recurrent disease resulting in death have been reported from its use [279]. Of the two histologically confirmed cases of melanoma treated with black salve, both developed metastatic disease [280,281].

Although vendors often list the ingredients of their black salve products, the concentration and shelf life of $S$. canadensis alkaloids is not stated and may not be known. To date, only one study has reported on the chemical composition of a single sample of black salve. This was a qualitative assessment that sought to detect constituents; their concentrations however were not reported [282]. S. canadensis alkaloids, as described, experience natural seasonal concentration variations and are impacted by a number of environmental and genetic factors. With compounds having broad bioactivity at micromolar concentrations, changes in salve alkaloid levels could result in unintended clinical effects.

\section{Future Application and Risks of Using S. canadensis}

The use of $S$. canadensis represents two different approaches to the therapeutic use of plants. Traditional medicines are developed by generations of indigenous people identifying and experimenting with biologically active natural products from very specific sources within their environment. These remedies often contain complex mixtures of organic chemicals derived from multiple botanical sources. In contrast, Western medicine has focused on identifying individual bioactive compounds with drug development potential via high throughput screening against molecular targets.

Both the traditional use and modern biological investigations of bloodroot suggest it warrants further study as a phytochemical extract and as a source of individual alkaloid lead compounds. Native Americans utilized the plant to treat a range of symptoms and conditions. Examining the in vitro bioactivity of individual alkaloids mechanistically supports these traditional uses. The anti-inflammatory, antimicrobial and anticancer capabilities of $S$. Canadensis, in particular, suggest further research is warranted.

Rational drug design has focused on a one compound, one target approach to minimize undesirable side effects that may arise from binding to secondary targets [283]. This philosophy has been challenged with the realization that drug promiscuity with polypharmacology is a mechanism by which a number of drugs exert their desired action [284]. Exquisitely selective compounds may reduce the risk of toxicity but may also less effectively treat disease. The alkaloids present in $S$. canadensis are phytoalexin allelochemicals capable of disrupting multiple cellular pathways. This broad bioactivity may exclude bloodroot alkaloids as classical drug candidates due to toxicity concerns. However, their ethnopharmacological history of use suggests the development of therapeutically effective doses, with toxicity levels acceptable to patients.

Indiscriminate cytotoxicity is of concern relating to black salve use. One in vitro study has suggested sanguinarine has a concentration dependent therapeutic window with a $2 \mu \mathrm{M}$ concentration showing preferential cytotoxicity to the A431 squamous cancer cell line compared to normal keratinocytes, this discriminating ability being lost at a $5 \mu \mathrm{M}$ concentration [285]. Other studies however have not supported this finding, with sanguinarine having equivalent cytotoxicity between tumor and normal cell lines [24] or actually having a greater cytotoxic effect on skin fibroblasts than the same A431 cell line [155]. Even if a sanguinarine therapeutic window exists, it is doubtful that natural 
therapies derived directly from S. canadensis rhizomes with their variable alkaloid composition would be able to target such a narrow pharmacological sweet spot. An assessment of black salve composition is urgently required to determine patient alkaloid exposures. This may offer an explanation for cases of skin cancer persistence due to subtherapeutic alkaloid levels and extensive tissue necrosis due to toxic alkaloid concentrations.

While the cellular cytotoxicity of individual alkaloids has been studied, the cytotoxicity of polyalkaloid extracts has received less attention. Antimicrobial research has shown S. canadensis alkaloid combinations exhibit four-fold greater potency than individual alkaloids against $H$. pylori [206] while alkaloid combinations have shown up to 10-fold improved killing of Trypanosoma brucei [286] suggesting they may have a synergistic effect. Whether phytochemical mixtures like black salve result in cellular cytotoxicity at concentrations lower than currently determined for individual alkaloids remains to be investigated.

The cytotoxic effect of an alkaloid mixture derived from Chelidonium majus has been assessed against murine fibroblast NIH/3T3, mouse melanoma B16F10, and human breast cancer MCF7 cell lines. The alkaloid mixture contained $3.3 \mu \mathrm{g} / \mathrm{mL}$ each of sanguinarine, protopine, allocryptopine, chelidonine and stylopine. It showed preferential melanoma cytotoxicity with $45 \%$ cell viability after 40 min compared to $75 \%$ normal cell viability. Unfortunately, a comparison with individual alkaloid cytotoxicity to determine the presence of alkaloid mixture synergy was not reported [287]. Although normal cells experienced a nearly two-fold greater alkaloid penetration, they experienced less cytotoxic effect due to preferential allocryptopine and stylopine permeability. In contrast, cancer cell lines showed greater penetration by sanguinarine and chelidonine.

The carcinogenic or mutagenic risk posed by S. canadensis botanical therapeutics is another area of clinical concern. S. canadensis mouthwash products cause leukoplakia, a pre-malignant condition. Skin cancers often develop within a field of genetically damaged cells [288], exposure to potentially genotoxic alkaloids could initiate or promote tumor development. Existing cancers if not destroyed by black salve may sustain further genetic damage rendering them more aggressive and treatment resistant.

Research specifically looking at sanguinarine's carcinogenic potential has yielded contradictory results. Female Swiss albino mice exposed to initiator 1,3-dimethylbutylamine (DMBA) with sanguinarine ( $4.5 \mu \mathrm{M}$ concentration) as a single application did not show an increased tumor development rate compared to DMBA application alone. In the same experiment, mice initiated with DMBA exposed to twice weekly topical $1.5 \mu \mathrm{M}$ sanguinarine for 25 weeks developed an earlier onset of tumorigenesis and increase in the mean tumor number per mouse from 5 for the DMBA/TPA initiation group to 7.07 for the DMBA/TPA initiation followed by 25-week sanguinarine application group [289]. This result suggests sanguinarine can act as a tumor promoter.

Another study however, in female SKH-1 hairless mice, showed sanguinarine had a protective effect against UVB mediated damage suggesting it may have a role in the prevention of skin cancer. A topical application of $5 \mu \mathrm{mol}$ sanguinarine, either as a pretreatment $30 \mathrm{~min}$ prior to UVB exposure, or a post-treatment 5 min after UVB exposure significantly reduced UVB induced skin oedema, hyperplasia and leukocyte infiltration [290]. Sanguinarine has been shown to induce apoptosis in UVB damaged HaCaT keratinocytes [291]. It also has an anti-oxidant effect achieved by blunting inflammatory cell oxidative bursts, not by operating as a free radical scavenger, but by disrupting NADPH oxidase [137]. By eliminating UV damaged cells and reducing UV-induced inflammatory changes, sanguinarine may protect against the development of skin cancer. The mixed story of cancer promotion and protection in different murine models requires clarification with future research especially considering these agents are currently being used by patients.

Patients believe natural plant therapies to be safer than manufactured pharmaceuticals [292]. Approximately $45 \%$ of the population in Western countries have used complementary and alternative medicine (CAM) within a 12-month period [293]. Concerns exist about the lack of regulatory control over the natural therapy sector and how this impacts quality control and patient safety [294]. With 
pharmaceutical products, manufacturers must provide regulators with safety and efficacy evidence before their product can be sold. In many countries, natural therapies may be sold without first demonstrating safety and efficacy, regulators bearing the burden of proving an agent is unsafe before it can be removed from the market [295]. A recent review of over the counter traditional Chinese medicine found that of 26 products, $92 \%$ had pharmaceutical, heavy metal contamination or substitution [296]. Safety is a key component of any human therapy; the lack of natural therapy regulatory control can leave patients vulnerable to toxicities that may be severe and life threatening.

\section{Conclusions}

S. canadensis is a traditional medicine with a variety of ethnopharmacological uses. Currently, the plant is used as an agricultural feed supplement; homeopathic remedy for menopausal flushing and osteoarthritis; and a cancer salve constituent. S. canadensis contains a number of bioactive alkaloids that have a range of molecular effects. Many factors have been shown to influence plant alkaloid concentrations which may impact the alkaloid composition of current bloodroot therapeutics.

S. canadensis cancer salves have a controversial history and have never been assessed in a clinical trial. The natural variation in S. canadensis alkaloids may offer an explanation for differing black salve clinical effects that warrants further exploration. The association of $S$. canadensis containing mouthwash with the development of leukoplakia and a murine model suggesting sanguinarine acts as a tumor promoter highlights the urgent need for studies into black salve carcinogenesis. Although regulators have issued warnings regarding black salve and have criminalized its importation in some jurisdictions, the therapy remains popular with patients interested in CAM.

Clinicians should engage with patients and discourage black salve use, especially for high risk skin cancers and those in cosmetically sensitive areas. As patients are currently using black salve, carefully designed observational studies could provide the fastest means of determining human in vivo toxicity and an assessment of its carcinogenic potential through tissue analysis of escharotic treated lesions. While such a reverse toxicology approach is not typical, removal of black salve treated areas could improve patient safety while providing relevant human tissue data. S. canadensis is a plant of therapeutic possibilities; the first step, however, should be to fully assess its safety.

Conflicts of Interest: The authors declare no conflict of interest.

\section{References}

1. Fabricant, D.S.; Farnsworth, N.R. The value of plants used in traditional medicine for drug discovery. Environ. Health Perspect. 2001, 109, 69-75. [CrossRef] [PubMed]

2. Vogel, V.J. American Indian Medicine; University of Oklahoma Press: Norman, OK, USA, 2013.

3. Mazzio, E.A.; Soliman, K.F. In vitro screening for the tumoricidal properties of international medicinal herbs. Phytother. Res. 2009, 23, 385-398. [CrossRef] [PubMed]

4. Slavik, J.; Slavikova, L. Alkaloide der mohngewächse (papaveraceae) XVII. Über neue alkaloide aus Sanguinaria canadensis L. Collect. Czechoslov. Chem. Commun. 1960, 25, 1667-1675. [CrossRef]

5. Damm, D.D.; Fantasia, J.E. White patch of maxillary vestibule. Sanguinarine-associated leukoplakia. Gen. Dent. 2002, 50, 466. [PubMed]

6. Lu, J.J.; Bao, J.L.; Chen, X.P.; Huang, M.; Wang, Y.T. Alkaloids isolated from natural herbs as the anticancer agents. Evid. Based Complement. Altern. Med. 2012, 2012, 485042. [CrossRef] [PubMed]

7. Bambagiotti-Alberti, M.; Pinzauti, S.; Moneti, G.; Gratteri, P.; Coran, S.A.; Vincieri, F.F. Characterization of Sanguinaria canadensis L. Fluid extract by fab mass spectrometry. J. Pharm. Biomed. Anal. 1991, 9, $1083-1087$. [CrossRef]

8. Malikova, J.; Zdarilova, A.; Hlobilkova, A. Effects of sanguinarine and chelerythrine on the cell cycle and apoptosis. Biomed. Pap. Med. Fac. Univ. Palacky Olomouc Czechoslov. 2006, 150, 5-12. [CrossRef]

9. Miao, F.; Yang, X.J.; Zhou, L.; Hu, H.J.; Zheng, F.; Ding, X.D.; Sun, D.M.; Zhou, C.D.; Sun, W. Structural modification of sanguinarine and chelerythrine and their antibacterial activity. Nat. Prod. Res. 2011, 25, 863-875. [CrossRef] [PubMed] 
10. Mackraj, I.; Govender, T.; Gathiram, P. Sanguinarine. Cardiovasc. Ther. 2008, 26, 75-83. [CrossRef] [PubMed]

11. Wink, M.; Schmeller, T.; Latz-Bruning, B. Modes of action of allelochemical alkaloids: Interaction with neuroreceptors, DNA, and other molecular targets. J. Chem. Ecol. 1998, 24, 1881-1937. [CrossRef]

12. Saeed, S.; Gilani, A.; Majoo, R.; Shah, B. Anti-thrombotic and anti-inflammatory activities of protopine. Pharmacol. Res. 1997, 36, 1-7. [CrossRef] [PubMed]

13. Kosina, P.; Walterova, D.; Ulrichova, J.; Lichnovsky, V.; Stiborova, M.; Rydlova, H.; Vicar, J.; Krecman, V.; Brabec, M.J.; Simanek, V. Sanguinarine and chelerythrine: Assessment of safety on pigs in ninety days feeding experiment. Food Chem. Toxicol. 2004, 42, 85-91. [CrossRef] [PubMed]

14. Hannah, J.J.; Johnson, J.D.; Kuftinec, M.M. Long-term clinical evaluation of toothpaste and oral rinse containing sanguinaria extract in controlling plaque, gingival inflammation, and sulcular bleeding during orthodontic treatment. Am. J. Orthod. Dentofac. Orthop. 1989, 96, 199-207. [CrossRef]

15. Jäggi, R.; Würgler, U.; Grandjean, F.; Weiser, M. Dual inhibition of 5-lipoxygenase/cyclooxygenase by a reconstituted homeopathic remedy; possible explanation for clinical efficacy and favourable gastrointestinal tolerability. Inflamm. Res. 2004, 53, 150-157. [CrossRef] [PubMed]

16. Hou, J.L.; Brewer, J.D. Black salve and bloodroot extract in dermatologic conditions. Cutis 2015, 95, 309-311. [PubMed]

17. Vlachojannis, C.; Magora, F.; Chrubasik, S. Rise and fall of oral health products with canadian bloodroot extract. Phytother. Res. 2012, 26, 1423-1426. [CrossRef] [PubMed]

18. Eastman, K.L.; McFarland, L.V.; Raugi, G.J. A review of topical corrosive black salve. J. Altern. Complement. Med. 2014, 20, 284-289. [CrossRef] [PubMed]

19. Laub, D.R., Jr. Death from metastatic basal cell carcinoma: Herbal remedy or just unlucky? J. Plast. Reconstr. Aesth. Surg. 2008, 61, 846-848. [CrossRef] [PubMed]

20. Salmore, A.K.; Hunter, M.D. Environmental and genotypic influences on isoquinoline alkaloid content in Sanguinaria canadensis. J. Chem. Ecol. 2001, 27, 1729-1747. [CrossRef] [PubMed]

21. Bennett, B.C.; Bell, C.R.; Boulware, R.T. Geographic variation in alkaloid content of Sanguinaria canadensis (Papaveraceae). Rhodora 1990, 92, 57-69.

22. Gaziano, R.; Moroni, G.; Buè, C.; Miele, M.T.; Sinibaldi-Vallebona, P.; Pica, F. Antitumor effects of the benzophenanthridine alkaloid sanguinarine: Evidence and perspectives. World J. Gastrointest. Oncol. 2016, 8, 30-39. [CrossRef] [PubMed]

23. Senchina, D.S.; Flinn, G.N.; McCann, D.A.; Kohut, M.L.; Shearn, C.T. Bloodroot (Sanguinaria canadensis L., papaveraceae) enhances proliferation and cytokine production by human peripheral blood mononuclear cells in an in vitro model. J. Herbs Spices Med. Plants 2009, 15, 45-65. [CrossRef] [PubMed]

24. Debiton, E.; Madelmont, J.C.; Legault, J.; Barthomeuf, C. Sanguinarine-induced apoptosis is associated with an early and severe cellular glutathione depletion. Cancer Chemother. Pharmacol. 2003, 51, 474-482. [PubMed]

25. Karp, J.M.; Rodrigo, K.A.; Pei, P.; Pavlick, M.D.; Andersen, J.D.; McTigue, D.J.; Fields, H.W.; Mallery, S.R. Sanguinarine activates polycyclic aromatic hydrocarbon associated metabolic pathways in human oral keratinocytes and tissues. Toxicol. Lett. 2005, 158, 50-60. [CrossRef] [PubMed]

26. Keith, C.T.; Borisy, A.A.; Stockwell, B.R. Multicomponent therapeutics for networked systems. Nat. Rev. Drug Discov. 2005, 4, 71-78. [CrossRef] [PubMed]

27. Ernst, W.R. The genera of papaveraceae and fumariaceae in the Southeastern United States. J. Arnold Arbor. 1962, 43, 315-343.

28. Nieuwland, J.A. Notes on the seedlings of bloodroot. Am. Midl. Nat. 1910, 1, 199-203. [CrossRef]

29. Parkinson, J. Theatrum Botanicum: The Theater of Plants, or, an Herball of a Large Extent; Tho. Cotes: London, UK, 1640; pp. 324-334.

30. Plukenet, L. Almagestum Botanicum; Sumptibus Auctoris: London, UK, 1696; pp. 279-280.

31. Felter, H.W.; Lloyd, J.U. Sanguinaria (u.S.P.)-Sanguinaria. In King's American Dispensatory; Ohio Valley Co.: Cincinnatti, OH, USA, 1898; pp. 1708-1714.

32. Dillen, J.J. Hortus Elthamensis seu Plantarum Rariorum quas in Horto suo Elthami in Cantio, Coluit... Jacobus Sherard,... Delineationes et Descriptiones... Auctore Johanne Jacobo Dillenio md; Sumptibus Auctoris: London, UK, 1732; pp. 334-336.

33. Linnaeus, C. Species Plantarum; Laurentii Salvii: Stockholm, Sweden, 1753; p. 505.

34. Rafinesque, C.S. Manual of the Medical Botany of the United States of North America; Atkinson \& Alexander: Philadelphia, PA, USA, 1830; Volume 2, pp. 78-81. 
35. Lyon, D.L. Bee pollination of facultatively xenogamous Sanguinaria canadensis L. Bull. Torrey Bot. Club 1992, 119, 368-375. [CrossRef]

36. Beattie, A.J.; Culver, D.C. The guild of myrmecochores in the herbaceous Flora of West Virginia forests. Ecology 1981, 62, 107-115. [CrossRef]

37. Pudlo, R.J.; Beattie, A.J.; Culver, D.C. Population consequences of changes in an ant-seed mutualism in Sanguinaria canadensis. Oecologia 1980, 46, 32-37. [CrossRef]

38. Gomez, C.; Espadaler, X. Myrmecochorous dispersal distances: A world survey. J. Biogeogr. 1998, 25, 573-580. [CrossRef]

39. Lobstein, M.B.; Rockwood, L.L. Influence of elaiosome removal on germination in five ant-dispersed plant species. Va. J. Sci. 1993, 44, 59-72.

40. Porter, S.D.; Savignano, D.A. Invasion of polygyne fire ants decimates native ants and disrupts arthropod community. Ecology 1990, 71, 2095-2106. [CrossRef]

41. Zettler, J.A.; Spira, T.P.; Allen, C.R. Ant-seed mutualisms: Can red imported fire ants sour the relationship? Biol. Conserv. 2001, 101, 249-253. [CrossRef]

42. Heithaus, E.R. Seed predation by rodents on three ant-dispersed plants. Ecology 1981, 136-145. [CrossRef]

43. Grieve, M.; Leyel, C.F. A Modern Herbal the Medicinal Culinary Cosmetic and Economic Properties Cultivation and Folk-Lore of Herbs, Grases Fungi, Shrubs \& Trees with All Their Modern Uses; Harcourt, Brace \& Co.: New York, NY, USA, 1931.

44. Fern, K. Plants for a Future: The Species Database. Available online: http://www.ibiblio.org/pfaf/database/ latinS.html (accessed on 8 May 2016).

45. Marino, P.C.; Eisenberg, R.M.; Cornell, H.V. Influence of sunlight and soil nutrients on clonal growth and sexual reproduction of the understory perennial herb Sanguinaria canadensis L. J. Torrey Bot. Soc. 1997, 219-227. [CrossRef]

46. Boothroyd-Roberts, K.; Gagnon, D.; Truax, B. Hybrid poplar plantations are suitable habitat for reintroduced forest herbs with conservation status. SpringerPlus 2013, 2, 507. [CrossRef] [PubMed]

47. Salmore, A.K.; Hunter, M.D. Elevational trends in defense chemistry, vegetation, and reproduction in Sanguinaria canadensis. J. Chem. Ecol. 2001, 27, 1713-1727. [CrossRef] [PubMed]

48. Erichsen-Brown, C. Medicinal and other Uses of North American Plants: A Historical Survey with Special Reference to the Eastern Indian Tribes; Courier Corporation: North Chelmsford, MA, USA, 2013.

49. Chamberlain, A.F. Algonkian words in american english: A study in the contact of the white man and the Indian. J. Am. Folk. 1902, 15, 240-267. [CrossRef]

50. Strachey, W. The Historie of Travaile into Virginia Britannia; Hakluyt Society: London, UK, 1849; p. 64.

51. Gilmore, M.R. Uses of Plants by the Indians of the Missouri River Region; University of Nebraska Press: Lincoln, NE, USA, 1991; pp. 44-45.

52. Herrick, J.W.; Snow, D.R. Iroquois Medical Botany; Syracuse University Press: Syracuse, NY, USA, 1995; pp. 127-128.

53. Smith, H.H. Ethnobotany of the Ojibwe Indians; Order of the Board of Trustees: Milwaukee, WI, USA, 1932; pp. 377-378.

54. Smith, H.H. Ethnobotany of the Forest Potawatomi Indians; AMS Press Inc.: New York, NY, USA, 1933; pp. 175-326.

55. Tantaquidgeon, G. A Study of Delaware Indian Medicine Practice and Folk Beliefs; Commonwealth of Pennsylvania, Departmet of Public Instruction, Pennsylvania Historical Commission: Harrisburg, PA, USA, 1942; p. 32.

56. Speck, F.G. Medicine practices of the Northeastern Algonquians; International Congress of Americanists: Washington, DC, USA, 1917; p. 318.

57. Densmore, F. Uses of plants by the Chippewa Indians. Bur. Am. Ethnol. Bull. 1928, 44, $275-397$.

58. Mechling, W.H. The malecite Indians, with notes on the Micmacs (concluded). Anthropologica 1959, 8, 161-274. [CrossRef]

59. Rousseau, J. Ethnobotanique abénaklse. Arch. Folk. 1947, 11, 145-182.

60. Sollenberger, R.R. Rappahannock field notes. Am. Philos. Soc. 1940.

61. Smith, H.H. Ethnobotany of the Meskwaki Indians; Public Museum of the City of Milwaukee: Milwaukee, WI, USA, 1928.

62. Chandler, R.F. Vindication of maritime Indian herbal remedies. J. Ethnopharmacol. 1983, 9, 323-327. [CrossRef] 
63. Hunter, J.D. Manners and Customs of several Indian Tribes Located West of the Mississippi: Including Some Account of the Soil, Climate, and Vegetable Productions, and the Indian Materia Medica: To Which Is Prefixed the History of the Author's Life during a Residence of Several Years among Them; Ross \& Haines: Minneapolis, PA, USA, 1823; p. 384.

64. Krochmal, A. Medicinal plants and Appalachia. Econ. Bot. 1968, 22, 332-337. [CrossRef]

65. Downey, W. An Investigation of the Properties of the Sanguinaria canadensis; or Puccoon; Eaken \& Mecum.: Philadelphia, PA, USA, 1803; pp. 23-25.

66. Gibb, G.D. The Sanguinaria canadensis: Its natural history, properties, and medical uses. BMJ 1860, 4, $104-107$. [CrossRef]

67. Allen, J.A. Remarks on the treatment of tracheitis, or croup. Boston Med. Surg. J. 1845, 33, 389-392. [CrossRef]

68. Eberle, J. A Treatise of the Materia Medica and Therapeutics; Grigg \& Elliot: Philadelphia, PA, USA, 1834; Volume 2, pp. 73-76.

69. Leonard, J. On the use of Sanguinaria. Boston Med. Surg. J. 1845, 32, 457-459. [CrossRef]

70. Leopold, D. A history of rhinology in North America. Otolaryngol. Head Neck Surg. 1996, 115, $283-297$. [CrossRef]

71. Barton, W.P.C. Vegetable Materia Medica of the United States, or, Medical Botany: Containing a Botanical, General, and Medical History, of Medicinal Plants Indigenous to the United States: Illustrated by Colored Engravings, Made after Original Drawings from Nature, Done by the Author; M. Carey \& Son: Philadelphia, PA, USA, 1817; pp. 30-42.

72. Thatcher, J. The American New Dispensatory, 2nd ed.; Thomas B. Wait \& Co. and C. Williams: Boston, MA, USA, 1813; pp. 201-204.

73. Bartholow, R. A Practical Treatise on Materia Medica and Therapeutics; D. Appleton: New York, NY, USA, 1888; pp. 359-361.

74. William, T. Sanguinarine and its salts: On the medicinal powers of sanguinarine and its salts. Boston Med. Surg. J. 1832, 6, 245-248. [CrossRef]

75. Mackentosh, J.; Holderwell, S. Receipts for the Cure of Most Diseases to the Human Family; U.S. National Library of Medicine: New York, NY, USA, 1827; p. 9.

76. Smith, D.B. On Sanguinaria canadensis. Boston Med. Surg. J. 1832, 5, 393-395. [CrossRef]

77. Ellingwood, F.; Lloyd, J.U. American Materia Medica, Therapeutics and Pharmacognosy: Developing the Latest Acquired Knowledge of Drugs, and Especially of the Direct Action of Single Drugs upon Exact Conditions of Disease, With Especial Reference to the Therapeutics of the Plant Drugs of the Americas; Ellingwoods' Therapeutist: Evanston, IL, USA, 1915; pp. 386-387.

78. Stillé, A. Therapeutics and Materia Medica; Blanchard and Lea: Philadelphia, PA, USA, 1874; Volume 2, pp. 454-457.

79. Cook, W. The Physiomedical Dispensatory; Wm. H. Cook: Cincinnati, OH, USA, 1869; pp. $466-467$.

80. Beach, W. The American Practice of Medicine; Betts \& Anstice: New York, NY, USA, 1833; Volume 2, pp. $259-261$.

81. Fell, J.W. A Treatise on Cancer, and Its Treatment; John Churchill: London, UK, 1857; pp. 59-63.

82. Shaw, A.D.M.C.; Moore, C.H.; Henry, M. Editorial. West. Lancet Mon. J. Pract. Med. Surg. 1857, 18, 541-542.

83. Hooper, S.N.; Chandler, R.F. Herbal remedies of the maritime Indians: Phytosterols and triterpenes of 67 plants. J. Ethnopharmacol. 1984, 10, 181-194. [CrossRef]

84. Dana, J.F. An account of some experiments on the root of the Sanguinaria canadensis. N. Y. Med. Phys. J. 1827, 6, 218-222. [CrossRef]

85. Probst, Q.M. Beschreibung und Dartsellungsweise einiger bei der Analyse de Chelidonium majus neu aufgefundenen Stoffe. Justus Liebigs Ann. Chem. 1839, 29, 113.

86. Konig, G. Über Papaveraceen-Alkaloïde. Arch. Pharm. 1893, 231, 177.

87. Gadamer, J.; Stichel, A. Chelerythrine and sanguinarine. Arch. Pharm. 1924, 262, 488-500.

88. Slavik, J. Alkaloide der mohngewachse (Papaveraceae) X. Uber die nebenalkaloide des klatschmohns (Papaver rhoeas L.) und der herzblume (Dicentra spectabilis L.). Collect. Czech. Chem. Commun. 1959, 24, 2506-2515. [CrossRef]

89. Suchomelova, J.; Bochorakova, H.; Paulova, H.; Musil, P.; Taborska, E. HPLC quantification of seven quaternary benzo[c]phenanthridine alkaloids in six species of the family papaveraceae. J. Pharm. Biomed. Anal. 2007, 44, 283-287. [CrossRef] [PubMed] 
90. Campbell, S.; Affolter, J.; Randle, W. Spatial and temporal distribution of the alkaloid sanguinarine in Sanguinaria canadensis L. (bloodroot). Econ. Bot. 2007, 61, 223-234. [CrossRef]

91. Homerberg, V.; Beringer, G. What is the proper time for the collection of sanguinaria? J. Am. Pharm. Assoc. 1913, 2, 1302. [CrossRef]

92. Farwell, O.A. The proper time to collect sanguinaria. Am. J. Pham. 1915, 87, 97-98.

93. Graf, T.N.; Levine, K.E.; Andrews, M.E.; Perlmutter, J.M.; Nielsen, S.J.; Davis, J.M.; Wani, M.C.; Oberlies, N.H. Variability in the yield of benzophenanthridine alkaloids in wildcrafted vs. cultivated bloodroot (Sanguinaria canadensis L.). J. Agric. Food Chem. 2007, 55, 1205-1211. [CrossRef] [PubMed]

94. Rho, D.; Chauret, N.; Laberge, N.; Archambault, J. Growth characteristics of Sanguinaria canadensis L. Cell suspensions and immobilized cultures for production of benzophenanthridine alkaloids. Appl. Microbiol. Biotechnol. 1992, 36, 611-617. [CrossRef] [PubMed]

95. Becci, P.J.; Schwartz, H.; Barnes, H.H.; Southard, G.L. Short-term toxicity studies of sanguinarine and of two alkaloid extracts of Sanguinaria canadensis L. J. Toxicol. Environ. Health 1987, 20, 199-208. [CrossRef] [PubMed]

96. Levin, D.A. Alkaloid-bearing plants: An ecogeographic perspective. Am. Nat. 1976, 110, 261-284. [CrossRef]

97. Jeanne, R.L. A latitudinal gradient in rates of ant predation. Ecology 1979, 60, 1211-1224. [CrossRef]

98. Levin, D.A. The toxicity of plant alkaloids: An ecogeographic perspective. Biochem. Syst. Ecol. 1978, 6, 61-76. [CrossRef]

99. Chandra, P.; Purohit, A. Berberine contents and alkaloid profile of berberis species from different altitudes. Biochem. Syst. Ecol. 1980, 8, 379-380. [CrossRef]

100. Carey, D.B.; Wink, M. Elevational variation of quinolizidine alkaloid contents in a lupine (Lupinus argenteus) of the Rocky Mountains. J. Chem. Ecol. 1994, 20, 849-857. [CrossRef] [PubMed]

101. Pencikova, K.; Urbanova, J.; Musil, P.; Taborska, E.; Gregorova, J. Seasonal variation of bioactive alkaloid contents in Macleaya microcarpa (Maxim.) Fedde. Molecules 2011, 16, 3391-3401. [CrossRef] [PubMed]

102. Arnason, J.; Guerin, B.; Kraml, M.; Mehta, B.; Redmond, R.; Scaiano, J. Phototoxic and photochemical properties of sanguinarine. Photochem. Photobiol. 1992, 55, 35-38. [CrossRef] [PubMed]

103. Maiti, M.; Nandi, R.; Chaudhuri, K. The effect of $\mathrm{PH}$ on the absorption and fluorescence-spectra of sanguinarine. Photochem. Photobiol. 1983, 38, 245-249. [CrossRef]

104. Jones, R.R.; Harkrader, R.J.; Southard, G.L. The effect of PH on sanguinarine iminium ion form. J. Nat. Prod. 1986, 49, 1109-1111. [CrossRef]

105. Bajaj, N.P.; McLean, M.J.; Waring, M.J.; Smekal, E. Sequence-selective, pH-dependent binding to DNA of benzophenanthridine alkaloids. J. Mol. Recognit. 1990, 3, 48-54. [CrossRef] [PubMed]

106. Todor, I. The effect of the antineoplastic drug ukrain on the electrokinetic potential of malignant and normal cells. Int. J. Immunother. 2003, 19, 159-168.

107. Maiti, M.; Das, S.; Sen, A.; Das, A.; Kumar, G.S.; Nandi, R. Influence of DNA structures on the conversion of sanguinarine alkanolamine form to iminium form. J. Biomol. Struct. Dyn. 2002, 20, 455-464. [CrossRef] [PubMed]

108. Slaninova, I.; Slanina, J.; Taborska, E. Quaternary benzo[c]phenanthridine alkaloids-Novel cell permeant and red fluorescing DNA probes. Cytom. A 2007, 71, 700-708. [CrossRef] [PubMed]

109. Bai, L.P.; Zhao, Z.Z.; Cai, Z.; Jiang, Z.H. DNA-binding affinities and sequence selectivity of quaternary benzophenanthridine alkaloids sanguinarine, chelerythrine, and nitidine. Bioorg. Med. Chem. 2006, 14, 5439-5445. [CrossRef] [PubMed]

110. Byrn, S.R.; Dolch, G.D. Analysis of binding of daunorubicin and doxorubicin to DNA using computerized curve-fitting procedures. J. Pharm. Sci. 1978, 67, 688-693. [CrossRef]

111. Messori, L.; Temperini, C.; Piccioli, F.; Animati, F.; Di Bugno, C.; Orioli, P. Solution chemistry and DNA binding properties of men 10755, a novel disaccharide analogue of doxorubicin. Bioorg. Med. Chem. 2001, 9, 1815-1825. [CrossRef]

112. Adhami, V.M.; Aziz, M.H.; Reagan-Shaw, S.R.; Nihal, M.; Mukhtar, H.; Ahmad, N. Sanguinarine causes cell cycle blockade and apoptosis of human prostate carcinoma cells via modulation of cyclin kinase inhibitor-cyclin-cyclin-dependent kinase machinery. Mol. Cancer Ther. 2004, 3, 933-940. [PubMed]

113. Nitiss, J.L. Targeting DNA topoisomerase ii in cancer chemotherapy. Nat. Rev. Cancer 2009, 9, 338-350. [CrossRef] [PubMed] 
114. Holy, J.; Lamont, G.; Perkins, E. Disruption of nucleocytoplasmic trafficking of cyclin D1 and topoisomerase II by sanguinarine. BMC Cell Biol. 2006, 7, 13. [CrossRef] [PubMed]

115. Vos, S.M.; Tretter, E.M.; Schmidt, B.H.; Berger, J.M. All tangled up: How cells direct, manage and exploit topoisomerase function. Nat. Rev. Mol. Cell Biol. 2011, 12, 827-841. [CrossRef] [PubMed]

116. Yang, D.; Okamoto, K. Structural insights into G-quadruplexes: Towards new anticancer drugs. Future Med. Chem. 2010, 2, 619-646. [CrossRef] [PubMed]

117. Bai, L.P.; Hagihara, M.; Jiang, Z.H.; Nakatani, K. Ligand binding to tandem g quadruplexes from human telomeric DNA. ChemBioChem 2008, 9, 2583-2587. [CrossRef] [PubMed]

118. Wen, L.N.; Xie, M.X. Competitive binding assay for G-quadruplex DNA and sanguinarine based on room temperature phosphorescence of Mn-doped ZnS quantum dots. J. Photochem. Photobiol. A Chem. 2014, 279, 24-31. [CrossRef]

119. Cummaro, A.; Fotticchia, I.; Franceschin, M.; Giancola, C.; Petraccone, L. Binding properties of human telomeric quadruplex multimers: A new route for drug design. Biochimie 2011, 93, 1392-1400. [CrossRef] [PubMed]

120. Ji, X.; Sun, H.; Zhou, H.; Xiang, J.; Tang, Y.; Zhao, C. The interaction of telomeric DNA and c-myc22 G-quadruplex with 11 natural alkaloids. Nucleic Acid Ther. 2012, 22, 127-136. [PubMed]

121. Lopus, M.; Panda, D. The benzophenanthridine alkaloid sanguinarine perturbs microtubule assembly dynamics through tubulin binding. A possible mechanism for its antiproliferative activity. FEBS J. 2006, 273, 2139-2150. [CrossRef] [PubMed]

122. Wolff, J.; Knipling, L. Antimicrotubule properties of benzophenanthridine alkaloids. Biochemistry 1993, 32, 13334-13339. [CrossRef] [PubMed]

123. Kinniburgh, A.J. A cis-acting transcription element of the $c$-myc gene can assume an H-DNA conformation. Nucleic Acids Res. 1989, 17, 7771-7778. [CrossRef] [PubMed]

124. Raghavan, S.C.; Chastain, P.; Lee, J.S.; Hegde, B.G.; Houston, S.; Langen, R.; Hsieh, C.-L.; Haworth, I.S.; Lieber, M.R. Evidence for a triplex DNA conformation at the Bcl-2 major breakpoint region of the $t(14 ; 18)$ translocation. J. Biol. Chem. 2005, 280, 22749-22760. [CrossRef] [PubMed]

125. Nelson, L.D.; Bender, C.; Mannsperger, H.; Buergy, D.; Kambakamba, P.; Mudduluru, G.; Korf, U.; Hughes, D.; Van Dyke, M.W.; Allgayer, H. Triplex DNA-binding proteins are associated with clinical outcomes revealed by proteomic measurements in patients with colorectal cancer. Mol. Cancer 2012, 11, 38. [CrossRef] [PubMed]

126. Latimer, L.J.; Payton, N.; Forsyth, G.; Lee, J.S. The binding of analogues of coralyne and related heterocyclics to DNA triplexes. Biochem. Cell Biol. 1995, 73, 11-18. [CrossRef] [PubMed]

127. Das, S.; Kumar, G.S.; Ray, A.; Maiti, M. Spectroscopic and thermodynamic studies on the binding of sanguinarine and berberine to triple and double helical DNA and RNA structures. J. Biomol. Struct. Dyn. 2003, 20, 703-713. [CrossRef] [PubMed]

128. Das, S.; Kumar, G.S.; Maiti, M. Conversions of the left-handed form and the protonated form of DNA back to the bound right-handed form by sanguinarine and ethidium: A comparative study. Biophys. Chem. 1999, 76, 199-218. [CrossRef]

129. Rich, A. Speculation on the biological roles of left-handed Z-DNA a . Ann. N. Y. Acad. Sci. 1994, 726, 1-17. [CrossRef] [PubMed]

130. Selvi, B.R.; Pradhan, S.K.; Shandilya, J.; Das, C.; Sailaja, B.S.; Shankar, G.N.; Gadad, S.S.; Reddy, A.; Dasgupta, D.; Kundu, T.K. Sanguinarine interacts with chromatin, modulates epigenetic modifications, and transcription in the context of chromatin. Chem. Biol. 2009, 16, 203-216. [CrossRef] [PubMed]

131. Gilbert, P.L.; Graves, D.E.; Britt, M.; Chaires, J.B. Inhibition of the B to Z transition in poly (dGdC). Cntdot. Poly (dGdC) by covalent attachment of ethidium: Kinetic studies. Biochemistry 1991, 30, 10931-10937. [CrossRef] [PubMed]

132. Giri, P.; Kumar, G.S. Molecular aspects of small molecules-poly(A) interaction: An approach to RNA based drug design. Curr. Med. Chem. 2009, 16, 965-987. [CrossRef] [PubMed]

133. Chowdhury, S.R.; Islam, M.M.; Kumar, G.S. Binding of the anticancer alkaloid sanguinarine to double stranded rnas: Insights into the structural and energetics aspects. Mol. Biosyst. 2010, 6, 1265-1276. [CrossRef] [PubMed]

134. Singh, C.K.; Kaur, S.; George, J.; Nihal, M.; Hahn, M.C.P.; Scarlett, C.O.; Ahmad, N. Molecular signatures of sanguinarine in human pancreatic cancer cells: A large scale label-free comparative proteomics approach. Oncotarget 2015, 6, 10335-10348. [CrossRef] [PubMed] 
135. Matkar, S.S.; Wrischnik, L.A.; Hellmann-Blumberg, U. Production of hydrogen peroxide and redox cycling can explain how sanguinarine and chelerythrine induce rapid apoptosis. Arch. Biochem. Biophys. 2008, 477, 43-52. [CrossRef] [PubMed]

136. Hussain, S.P.; Amstad, P.; He, P.; Robles, A.; Lupold, S.; Kaneko, I.; Ichimiya, M.; Sengupta, S.; Mechanic, L.; Okamura, S. P53-induced up-regulation of MnSOD and GPx but not catalase increases oxidative stress and apoptosis. Cancer Res. 2004, 64, 2350-2356. [CrossRef] [PubMed]

137. Vrba, J.; Hrbac, J.; Ulrichova, J.; Modriansky, M. Sanguinarine is a potent inhibitor of oxidative burst in DMSO-differentiated HL-60 cells by a non-redox mechanism. Chem. Biol. Interact. 2004, 147, 35-47. [CrossRef] [PubMed]

138. Slaninova, I.; Pencikova, K.; Urbanova, J.; Slanina, J.; Taborska, E. Antitumour activities of sanguinarine and related alkaloids. Phytochem. Rev. 2014, 13, 51-68. [CrossRef]

139. Gu, S.; Yang, X.-C.; Xiang, X.-Y.; Wu, Y.A.O.; Zhang, Y.U.; Yan, X.-Y.; Xue, Y.-N.; Sun, L.-K.; Shao, G.-G. Sanguinarine-induced apoptosis in lung adenocarcinoma cells is dependent on reactive oxygen species production and endoplasmic reticulum stress. Oncol. Rep. 2015, 34, 913-919. [CrossRef]

140. Malhotra, J.D.; Kaufman, R.J. The Endoplasmic Reticulum and the Unfolded Protein Response. Semin. Cell Dev. Biol. 2007, 18, 716-731. [CrossRef] [PubMed]

141. Malhotra, J.D.; Kaufman, R.J. Er stress and its functional link to mitochondria: Role in cell survival and death. Cold Spring Harb. Perspect. Biol. 2011, 3, a004424. [CrossRef] [PubMed]

142. Malhotra, J.D.; Kaufman, R.J. Endoplasmic reticulum stress and oxidative stress: A vicious cycle or a double-edged sword? Antioxid. Redox Signal. 2007, 9, 2277-2294. [CrossRef] [PubMed]

143. Sanchez-Lopez, E.; Zimmerman, T.; Gomez del Pulgar, T.; Moyer, M.P.; Lacal Sanjuan, J.C.; Cebrian, A. Choline kinase inhibition induces exacerbated endoplasmic reticulum stress and triggers apoptosis via chop in cancer cells. Cell Death Dis. 2013, 4, e933. [CrossRef] [PubMed]

144. Coffey, R.N.; Watson, R.W.G.; Hegarty, N.J.; O’Neill, A.; Gibbons, N.; Brady, H.R.; Fitzpatrick, J.M. Thiol-mediated apoptosis in prostate carcinoma cells. Cancer 2000, 88, 2092-2104. [CrossRef]

145. Hall, A. The role of glutathione in the regulation of apoptosis. Eur. J. Clin. Investig. 1999, 29, $238-245$. [CrossRef]

146. Kerbel, R.S. Tumor angiogenesis. N. Engl. J. Med. 2008, 358, 2039-2049. [CrossRef] [PubMed]

147. Kerbel, R.; Folkman, J. Clinical translation of angiogenesis inhibitors. Nat. Rev. Cancer 2002, 2, 727-739. [CrossRef] [PubMed]

148. Eun, J.P.; Koh, G.Y. Suppression of angiogenesis by the plant alkaloid, sanguinarine. Biochem. Biophys. Res. Commun. 2004, 317, 618-624. [CrossRef] [PubMed]

149. De Stefano, I.; Raspaglio, G.; Zannoni, G.F.; Travaglia, D.; Prisco, M.G.; Mosca, M.; Ferlini, C.; Scambia, G.; Gallo, D. Antiproliferative and antiangiogenic effects of the benzophenanthridine alkaloid sanguinarine in melanoma. Biochem. Pharmacol. 2009, 78, 1374-1381. [CrossRef] [PubMed]

150. Malikova, J.; Zdarilova, A.; Hlobilkova, A.; Ulrichova, J. The effect of chelerythrine on cell growth, apoptosis, and cell cycle in human normal and cancer cells in comparison with sanguinarine. Cell Biol. Toxicol. 2006, 22, 439-453. [CrossRef] [PubMed]

151. Chmura, S.J.; Dolan, M.E.; Cha, A.; Mauceri, H.J.; Kufe, D.W.; Weichselbaum, R.R. In vitro and in vivo activity of protein kinase $C$ inhibitor chelerythrine chloride induces tumor cell toxicity and growth delay in vivo. Clin. Cancer Res. 2000, 6, 737-742. [PubMed]

152. Yu, R.; Mandlekar, S.; Tan, T.-H.; Kong, A.-N.T. Activation of p38 and c-Jun N-terminal kinase pathways and induction of apoptosis by chelerythrine do not require inhibition of protein kinase C. J. Biol. Chem. 2000, 275, 9612-9619. [CrossRef] [PubMed]

153. Chan, S.-L.; Lee, M.C.; Tan, K.O.; Yang, L.-K.; Lee, A.S.; Flotow, H.; Fu, N.Y.; Butler, M.S.; Soejarto, D.D.; Buss, A.D. Identification of Chelerythrine as an inhibitor of BclXL function. J. Biol. Chem. 2003, 278, 20453-20456. [CrossRef] [PubMed]

154. Medvetz, D.; Priolo, C.; Henske, E.P. Therapeutic targeting of cellular metabolism in cells with hyperactive mTORC1: A paradigm shift. Mol. Cancer Res. 2015, 13, 3-8. [CrossRef] [PubMed]

155. Slaninova, I.; Slunska, Z.; Sinkora, J.; Vlkova, M.; Taborska, E. Screening of minor benzo[c]phenanthridine alkaloids for antiproliferative and apoptotic activities. Pharm. Biol. 2007, 45, 131-139. [CrossRef] 
156. Hammerova, J.; Uldrijan, S.; Taborska, E.; Slaninova, I. Benzo[c]phenanthridine alkaloids exhibit strong anti-proliferative activity in malignant melanoma cells regardless of their p53 status. J. Dermatol. Sci. 2011, 62, 22-35. [CrossRef] [PubMed]

157. Slunska, Z.; Gelnarova, E.; Hammerova, J.; Taborska, E.; Slaninova, I. Effect of quaternary benzo[c]phenanthridine alkaloids sanguilutine and chelilutine on normal and cancer cells. Toxicol. in Vitro 2010, 24, 697-706. [CrossRef] [PubMed]

158. Hammerova, J.; Uldrijan, S.; Taborska, E.; Vaculova, A.H.; Slaninova, I. Necroptosis modulated by autophagy is a predominant form of melanoma cell death induced by sanguilutine. Biol. Chem. 2012, 393, 647-658. [CrossRef] [PubMed]

159. Vandenabeele, P.; Galluzzi, L.; Berghe, T.V.; Kroemer, G. Molecular mechanisms of necroptosis: An ordered cellular explosion. Nat. Rev. Mol. Cell Biol. 2010, 11, 700-714. [CrossRef] [PubMed]

160. Xiao, C.; Yuan, Y.; Ding, Y.Z.; Jin, T.F.; Pei, G. Study on the alkaloids from the stem of zanthoxylum dissitum. Zhong Yao Cai 2011, 34, 551-553. [PubMed]

161. He, K.; Gao, J.-L. Protopine inhibits heterotypic celladhesion in MDA-MB-231 cells through down-regulation of multi-adhesive factors. Afr. J. Tradit. Complement. Altern. Med. 2014, 11, 415-424. [CrossRef] [PubMed]

162. Chaturvedi, M.M.; Kumar, A.; Darnay, B.G.; Chainy, G.B.; Agarwal, S.; Aggarwal, B.B. Sanguinarine (pseudochelerythrine) is a potent inhibitor of NF- $\mathrm{B}$ activation, I $\alpha \alpha$ phosphorylation, and degradation. J. Biol. Chem. 1997, 272, 30129-30134. [CrossRef] [PubMed]

163. Bernardo, P.H.; Wan, K.F.; Sivaraman, T.; Xu, J.; Moore, F.K.; Hung, A.W.; Mok, H.Y.K.; Yu, V.C.; Chai, C.L.L. Structure-activity relationship studies of phenanthridine-based Bcl-Xl inhibitors. J. Med. Chem. 2008, 51, 6699-6710. [CrossRef] [PubMed]

164. Yang, S.; Xiang, J.F.; Yang, Q.F.; Li, Q.A.; Zhou, Q.J.; Zhang, X.F.; Tang, Y.L.; Xu, G.Z. Formation of human telomeric G-quadruplex structures induced by the quaternary benzophenanthridine alkaloids: Sanguinarine, nitidine, and chelerythrine. Chin. J. Chem. 2010, 28, 771-780. [CrossRef]

165. Ahsan, H.; Reagan-Shaw, S.; Breur, J.; Ahmad, N. Sanguinarine induces apoptosis of human pancreatic carcinoma AsPC-1 and BxPC-3 cells via modulations in Bcl-2 family proteins. Cancer Lett. 2007, 249, 198-208. [CrossRef] [PubMed]

166. Han, M.H.; Kim, S.O.; Kim, G.Y.; Kwon, T.K.; Choi, B.T.; Lee, W.H.; Choi, Y.H. Induction of apoptosis by sanguinarine in $\mathrm{C} 6$ rat glioblastoma cells is associated with the modulation of the Bcl-2 family and activation of caspases through downregulation of extracellular signal-regulated kinase and Akt. Anticancer Drugs 2007, 18, 913-921. [PubMed]

167. Hussain, A.R.; Al-Jomah, N.A.; Siraj, A.K.; Pulicat, M.S.; Al-Hussein, K.A.; Al-Kuraya, K.S.; Uddin, S. Up-regulation of death receptor 5 and bax translocation is necessary to induce apoptosis by sanguinarine in primary effusion lymphoma. Blood 2006, 108, 234B.

168. Ghosh, S.; Jana, J.; Kar, R.K.; Chatterjee, S.; Dasgupta, D. Plant alkaloid chelerythrine induced aggregation of human telomere sequence-A unique mode of association between a small molecule and a quadruplex. Biochemistry 2015, 54, 974-986. [CrossRef] [PubMed]

169. Barreto, M.C.; Pinto, R.E.; Arrabaca, J.D.; Pavao, M.L. Inhibition of mouse liver respiration by Chelidonium majus isoquinoline alkaloids. Toxicol. Lett. 2003, 146, 37-47. [CrossRef] [PubMed]

170. Thomas, A.G.; Rojas, C.; Tanega, C.; Shen, M.; Simeonov, A.; Boxer, M.B.; Auld, D.S.; Ferraris, D.V.; Tsukamoto, T.; Slusher, B.S. Kinetic characterization of ebselen, chelerythrine and apomorphine as glutaminase inhibitors. Biochem. Biophys. Res. Commun. 2013, 438, 243-248. [CrossRef] [PubMed]

171. Shemon, A.N.; Sluyter, R.; Conigrave, A.D.; Wiley, J.S. Chelerythrine and other benzophenanthridine alkaloids block the human $\mathrm{P} \mathrm{X}_{7}$ receptor. Br. J. Pharmacol. 2004, 142, 1015-1019. [CrossRef] [PubMed]

172. Tan, I.; Lai, J.; Yong, J.; Li, S.F.Y.; Leung, T. Chelerythrine perturbs lamellar actomyosin filaments by selective inhibition of myotonic dystrophy kinase-related Cdc42-binding kinase. FEBS Lett. 2011, 585, 1260-1268. [CrossRef] [PubMed]

173. Zhang, Z.-F.; Guo, Y.; Zhang, J.-B.; Wei, X.-H. Induction of apoptosis by chelerythrine chloride through mitochondrial pathway and Bcl-2 family proteins in human hepatoma SMMC-7721 cell. Arch. Pharm. Res. 2011, 34, 791-800. [CrossRef] [PubMed] 
174. Slaninová, I.; Táborská, E.; Bochořáková, H.; Slanina, J. Interaction of benzo[c]phenanthridine and protoberberine alkaloids with animal and yeast cells. Cell Biol. Toxicol. 2001, 17, 51-63. [CrossRef] [PubMed]

175. Xiao, X.; Liu, J.; Hu, J.; Zhu, X.; Yang, H.; Wang, C.; Zhang, Y. Protective effects of protopine on hydrogen peroxide-induced oxidative injury of PC12 cells via $\mathrm{Ca}^{2+}$ antagonism and antioxidant mechanisms. Eur. J. Pharmacol. 2008, 591, 21-27. [CrossRef] [PubMed]

176. Schmeller, T.; Latz-Brüning, B.; Wink, M. Biochemical activities of berberine, palmatine and sanguinarine mediating chemical defence against microorganisms and herbivores. Phytochemistry 1997, 44, 257-266. [CrossRef]

177. Caballero-George, C.; Vanderheyden, P.M.; Apers, S.; van den Heuvel, H.; Solis, P.N.; Gupta, M.P.; Claeys, M.; Pieters, L.; Vauquelin, G.; Vlietinck, A.J. Inhibitory activity on binding of specific ligands to the human angiotensin II $\mathrm{AT}_{1}$ and endothelin 1 ETA receptors: Bioactive benzo[c]phenanthridine alkaloids from the root of Bocconia frutescens. Planta Med. 2002, 68, 770-775. [CrossRef]

178. Caballero-George, C.; Vanderheyden, P.; Solis, P.; Pieters, L.; Shahat, A.; Gupta, M.; Vauquelin, G.; Vlietinck, A. Biological screening of selected medicinal panamanian plants by radioligand-binding techniques. Phytomedicine 2001, 8, 59-70. [CrossRef] [PubMed]

179. Caballero-George, C.; Vanderheyden, P.M.L.; Solis, P.N.; Gupta, M.P.; Pieters, L.; Vauquelin, G.; Vlietinck, A. In vitro effect of sanguinarine alkaloid on binding of $\left[{ }^{3} \mathrm{H}\right]$ candesartan to the human angiotensin $\mathrm{AT}_{1}$ receptor. Eur. J. Pharmacol. 2003, 458, 257-262. [CrossRef]

180. Li, B.; Wu, Q.; Shi, J.-S.; Sun, A.-S.; Huang, X.-N. Effects of protopine on intracellular calcium and the PKC activity of rat aorta smooth muscle. Sheng Li Xue Bao 2005, 57, 240-246. [PubMed]

181. Seifen, E.; Adams, R.J.; Riemer, R.K. Sanguinarine: A positive inotropic alkaloid which inhibits cardiac $\mathrm{Na}^{+}, \mathrm{K}^{+}$-ATPase. Eur. J. Pharmacol. 1979, 60, 373-377. [CrossRef]

182. Song, L.S.; Ren, G.J.; Chen, Z.L.; Chen, Z.H.; Zhou, Z.N.; Cheng, H. Electrophysiological effects of protopine in cardiac myocytes: Inhibition of multiple cation channel currents. Br. J. Pharmacol. 2000, 129, 893-900. [CrossRef] [PubMed]

183. Li, Y.; Wang, S.; Liu, Y.; Li, Z.; Yang, X.; Wang, H.; Wen, Y.; Chen, Y. Effect of $\alpha$-allocryptopine on transient outward potassium current in rabbit ventricular myocytes. Cardiology 2008, 111, 229-236. [CrossRef] [PubMed]

184. Akbarov, Z.S.; Aliev, K.; Sultanov, M.B. Comparative study of the anti-arrhythmic action of the alkaloid a-allocryptopine with quinidine. Dokl. Akad. Nauk Uzb. 1972, 29, 38.

185. Yamamoto, S.; Seta, K.; Morisco, C.; Vatner, S.F.; Sadoshima, J. Chelerythrine rapidly induces apoptosis through generation of reactive oxygen species in Cardiac myocytes. J. Mol. Cell. Cardiol. 2001, 33, 1829-1848. [CrossRef] [PubMed]

186. Bae, D.S.; Kim, Y.H.; Pan, C.-H.; Nho, C.W.; Samdan, J.; Yansan, J.; Lee, J.K. Protopine reduces the inflammatory activity of lipopolysaccharide-stimulated murine macrophages. BMB Rep. 2012, 45, 108. [CrossRef] [PubMed]

187. Niu, X.-F.; Zhou, P.; Li, W.-F.; Xu, H.-B. Effects of chelerythrine, a specific inhibitor of cyclooxygenase-2, on acute inflammation in mice. Fitoterapia 2011, 82, 620-625. [CrossRef] [PubMed]

188. Vavreckova, C.; Gawlik, I.; Muller, K. Benzophenanthridine alkaloids of chelidonium majus; I. Inhibition of 5- and 12-lipoxygenase by a non-redox mechanism. Planta Med. 1996, 62, 397-401. [CrossRef] [PubMed]

189. Siomboing, X.; Gressier, B.; Dine, T.; Brunet, C.; Luyckx, M.; Cazin, M.; Cazin, J.-C. Investigation of the inhibitory effects of chelerythrine chloride on the translocation of the protein kinase $\mathrm{c} \beta \mathrm{i}, \beta \mathrm{ii}, \zeta$ in human neutrophils. IL Farmaco 2001, 56, 859-865. [CrossRef]

190. Vrba, J.; Dvorak, Z.; Ulrichova, J.; Modriansky, M. Conventional protein kinase c isoenzymes undergo dephosphorylation in neutrophil-like HL-60 cells treated by chelerythrine or sanguinarine. Cell Biol. Toxicol. 2008, 24, 39-53. [CrossRef] [PubMed]

191. Whyte, M.; Meagher, L.C.; MacDermot, J.; Haslett, C. Impairment of function in aging neutrophils is associated with apoptosis. J. Immunol. 1993, 150, 5124-5134. [PubMed]

192. Haslett, C. Resolution of acute inflammation and the role of apoptosis in the tissue fate of granulocytes. Clin. Sci. 1992, 83, 639-648. [CrossRef] [PubMed]

193. Grigg, J.; Silverman, M.; Savill, J.; Sarraf, C.; Haslett, C. Neutrophil apoptosis and clearance from neonatal lungs. Lancet 1991, 338, 720-722. [CrossRef] 
194. Savill, J.; Smith, J.; Sarraf, C.; Ren, Y.; Abbott, F.; Rees, A. Glomerular mesangial cells and inflammatory macrophages ingest neutrophils undergoing apoptosis. Kidney Int. 1992, 42, 924-936. [CrossRef] [PubMed]

195. Sweeney, J.F.; Nguyen, P.K.; Atkins, K.B.; Hinshaw, D.B. Chelerythrine chloride induces rapid polymorphonuclear leukocyte apoptosis through activation of caspase-3. Shock 2000, 13, 464-471. [CrossRef] [PubMed]

196. Albelda, S.M.; Smith, C.W.; Ward, P. Adhesion molecules and inflammatory injury. FASEB J. 1994, 8, 504-512. [PubMed]

197. Tang, M.; Fiscus, L. Important roles for 1-selectin and icam-1 in the development of allergic airway inflammation in asthma. Pulm. Pharmacol. Ther. 2001, 14, 203-210. [CrossRef] [PubMed]

198. Mukhopadhyay, S.; Malik, P.; Arora, S.K.; Mukherjee, T.K. Intercellular adhesion molecule-1 as a drug target in asthma and rhinitis. Respirology 2014, 19, 508-513. [CrossRef] [PubMed]

199. Yang, C.M.; Luo, S.F.; Hsieh, H.L.; Chi, P.L.; Lin, C.C.; Wu, C.C.; Hsiao, L.D. Interleukin-1 $\beta$ induces ICAM-1 expression enhancing leukocyte adhesion in human rheumatoid arthritis synovial fibroblasts: Involvement of erk, JNK, AP-1, and NF-kB. J. Cell. Physiol. 2010, 224, 516-526. [CrossRef] [PubMed]

200. Van Kuijk, A.W.; Reinders-Blankert, P.; Smeets, T.J.; Dijkmans, B.A.; Tak, P.P. Detailed analysis of the cell infiltrate and the expression of mediators of synovial inflammation and joint destruction in the synovium of patients with psoriatic arthritis: Implications for treatment. Ann. Rheum. Dis. 2006, 65, 1551-1557. [CrossRef] [PubMed]

201. Tanaka, S.; Sakata, Y.; Morimoto, K.; Tambe, Y.; Watanabe, Y.; Honda, G.; Tabata, M.; Oshima, T.; Masuda, T.; Umezawa, T. Influence of natural and synthetic compounds on cell surface expression of cell adhesion molecules, ICAM-1 and VCAM-1. Planta Med. 2001, 67, 108-113. [CrossRef] [PubMed]

202. Obiang-Obounou, B.W.; Kang, O.H.; Choi, J.G.; Keum, J.H.; Kim, S.B.; Mun, S.H.; Shin, D.W.; Kim, K.W.; Park, C.B.; Kim, Y.G.; et al. The mechanism of action of sanguinarine against methicillin-resistant staphylococcus aureus. J. Toxicol. Sci. 2011, 36, 277-283. [CrossRef] [PubMed]

203. Hamoud, R.; Reichling, J.; Wink, M. Synergistic antimicrobial activity of combinations of sanguinarine and edta with vancomycin against multidrug resistant bacteria. Drug Metab. Lett. 2014, 8, 119-128. [CrossRef] [PubMed]

204. Dzink, J.L.; Socransky, S.S. Comparative in vitro activity of sanguinarine against oral microbial isolates. Antimicrob. Agents Chemother. 1985, 27, 663-665. [CrossRef] [PubMed]

205. Graham, D.Y.; Fischbach, L. Helicobacter pylori treatment in the era of increasing antibiotic resistance. Gut 2010, 59, 1143-1153. [CrossRef] [PubMed]

206. Mahady, G.B.; Pendland, S.L.; Stoia, A.; Chadwick, L.R. In vitro susceptibility of Helicobacter pylori to isoquinoline alkaloids from Sanguinaria canadensis and Hydrastis canadensis. Phytother. Res. 2003, 17, 217-221. [CrossRef] [PubMed]

207. Newton, S.M.; Lau, C.; Gurcha, S.S.; Besra, G.S.; Wright, C.W. The evaluation of forty-three plant species for in vitro antimycobacterial activities; isolation of active constituents from Psoralea corylifolia and Sanguinaria canadensis. J. Ethnopharmacol. 2002, 79, 57-67. [CrossRef]

208. Seubert, J.; Pohlke, R.; Loebich, F. Synthesis and properties of praziquantel, a novel broad spectrum anthelmintic with excellent activity against schistosomes and cestodes. Experientia 1977, 33, 1036-1037. [CrossRef] [PubMed]

209. Ismail, M.; Botros, S.; Metwally, A.; William, S.; Farghally, A.; Tao, L.-F.; Day, T.A.; Bennett, J.L. Resistance to praziquantel: Direct evidence from schistosoma mansoni isolated from Egyptian villagers. Am. J. Trop. Med. Hyg. 1999, 60, 932-935. [PubMed]

210. Zhang, S.-M.; Coultas, K.A. Identification of plumbagin and sanguinarine as effective chemotherapeutic agents for treatment of schistosomiasis. Int. J. Parasitol. Drugs Drug Resist. 2013, 3, 28-34. [CrossRef] [PubMed]

211. Schär, F.; Trostdorf, U.; Giardina, F.; Khieu, V.; Muth, S.; Marti, H.; Vounatsou, P.; Odermatt, P. Strongyloides stercoralis: Global distribution and risk factors. PLoS Negl. Trop. Dis. 2013, 7, e2288. [CrossRef] [PubMed]

212. Segarra-Newnham, M. Manifestations, diagnosis, and treatment of strongyloides stercoralis infection. Ann. Pharmacother. 2007, 41, 1992-2001. [CrossRef] [PubMed] 
213. Satou, T.; Koga, M.; Matsuhashi, R.; Koike, K.; Tada, I.; Nikaido, T. Assay of nematocidal activity of isoquinoline alkaloids using third-stage larvae of Strongyloides ratti and S. Venezuelensis. Vet. Parasitol. 2002, 104, 131-138. [CrossRef]

214. Kaewviyudth, S.; Chinabut, S. Five new species of Dactylogyrus (Monogenea) from cyprimd fishes in Thailand. Asian Fish. Sci. 1999, 12, 391-399.

215. Wang, G.X.; Zhou, Z.; Jiang, D.X.; Han, J.; Wang, J.F.; Zhao, L.W.; Li, J. In vivo anthelmintic activity of five alkaloids from Macleaya microcarpa (Maxim.) fedde against Dactylogyrus intermedius in Carassius auratus. Vet. Parasitol. 2010, 171, 305-313. [CrossRef] [PubMed]

216. Satou, T.; Akao, N.; Matsuhashi, R.; Koike, K.; Fujita, K.; Nikaido, T. Inhibitory effect of isoquinoline alkaloids on movement of second-stage larvae of Toxocara canis. Biol. Pharm. Bull. 2002, 25, 1651-1654. [CrossRef] [PubMed]

217. Cheng, T.J.; Goodsell, D.S.; Kan, C.C. Identification of sanguinarine as a novel HIV protease inhibitor from high-throughput screening of 2000 drugs and natural products with a cell-based assay. Lett. Drug Des. Discov. 2005, 2, 364-371. [CrossRef]

218. Orhan, I.; Özcelik, B.; Şener, B. Antiviral and Antimicrobial Evaluation of Some Heterocyclic Compounds from Turkish Plants; Springer: Berlin, Germany, 2007; Volume 11, pp. 303-323.

219. Wangchuk, P.; Bremner, J.B.; Rattanajak, R.; Kamchonwongpaisan, S. Antiplasmodial agents from the bhutanese medicinal plant Corydalis calliantha. Phytother. Res. 2010, 24, 481-485. [CrossRef] [PubMed]

220. Rosenkranz, V.; Wink, M. Alkaloids induce programmed cell death in bloodstream forms of trypanosomes (Trypanosoma b. brucei). Molecules 2008, 13, 2462-2473. [CrossRef] [PubMed]

221. Meng, F.; Zuo, G.; Hao, X.; Wang, G.; Xiao, H.; Zhang, J.; Xu, G. Antifungal activity of the benzo[c]phenanthridine alkaloids from Chelidonium majus Linn against resistant clinical yeast isolates. J. Ethnopharmacol. 2009, 125, 494-496. [CrossRef] [PubMed]

222. Pong Ng, Y.; Tsun Or, T.C.; Ip, N.Y. Plant alkaloids as drug leads for Alzheimer's disease. Neurochem. Int. 2015, 89, 260-270.

223. Kim, S.R.; Hwang, S.Y.; Jang, Y.P.; Park, M.J.; Markelonis, G.J.; Oh, T.H.; Kim, Y.C. Protopine from corydalis ternata has anticholinesterase and antiamnesic activities. Planta Med. 1999, 65, 218-221. [CrossRef] [PubMed]

224. Kim, D.K.; Lee, K.T.; Baek, N.-I.; Kim, S.-H.; Park, H.W.; Lim, J.P.; Shin, T.Y.; Eom, D.O.; Yang, J.H.; Eun, J.S. Acetylcholinesterase inhibitors from the aerial parts of Corydalis speciosa. Arch. Pharm. Res. 2004, 27, 1127-1131. [CrossRef] [PubMed]

225. Şener, B.; Orhan, İ. Discovery of drug candidates from some turkish plants and conservation of biodiversity. Pure Appl. Chem. 2005, 77, 53-64. [CrossRef]

226. Zheng, W.; Qiu, L.; Wang, R.; Feng, X.; Han, Y.; Zhu, Y.; Chen, D.; Liu, Y.; Jin, L.; Li, Y. Selective targeting of PPAR $\Gamma$ by the natural product chelerythrine with a unique binding mode and improved antidiabetic potency. Sci. Rep. 2015, 5, 12222. [CrossRef] [PubMed]

227. Lee, K.H.; Huh, J.; Choi, M.; Yoon, S.Y.; Yang, S.; Hong, H.; Cho, S. Regulation of glutamate level in rat brain through activation of glutamate dehydrogenase by Corydalis ternata. Exp. Mol. Med. 2005, 37, 371-377. [CrossRef] [PubMed]

228. Xu, L.-F.; Chu, W.-J.; Qing, X.-Y.; Li, S.; Wang, X.-S.; Qing, G.-W.; Fei, J.; Guo, L.-H. Protopine inhibits serotonin transporter and noradrenaline transporter and has the antidepressant-like effect in mice models. Neuropharmacology 2006, 50, 934-940. [CrossRef] [PubMed]

229. Engel, R. Ueber Das Protopin. Naunyn Schmiedebergs Arch. Exp. Pathol. Pharmakol. 1890, $27,419-431$. [CrossRef]

230. Goto, K.; Oda, R. Studies on the Alkaloids of Macleya cordata R. J. Pharm. Soc. Jpn. 1949, 69, 307.

231. Abu-Ghalyun, Y.; Masalmeh, A.; Al-Khalil, S. Effects of allocryptopine, an alkaloid isolated from glaucium arabicum on rat isolated ileum and urinary bladder. Gen. Pharmacol. Vasc. Syst. 1997, 29, 621-623. [CrossRef]

232. Üstünes, L.; Laekeman, G.M.; Gözler, B.; Vlietinck, A.J.; Özer, A.; Herman, A.G. In vitro study of the anticholinergic and antihistaminic activities of protopine and some derivatives. J. Nat. Prod. 1988, 51, 1021-1022. [CrossRef] [PubMed]

233. Jeng, J.H.; Wu, H.L.; Lin, B.R.; Lan, W.H.; Chang, H.H.; Ho, Y.S.; Lee, P.H.; Wang, Y.J.; Wang, J.S.; Chen, Y.J.; et al. Antiplatelet effect of sanguinarine is correlated to calcium mobilization, thromboxane and camp production. Atherosclerosis 2007, 191, 250-258. [CrossRef] [PubMed] 
234. European Union. Ban on Antibiotics as Growth Promoters in Animal Feed Enters into Effect (1831/2003/ec); European Commission: Brussels, Belgium, 2005.

235. Roth, R.; Kirchgessner, M. Organic acids as feed additives for young pigs: Nutritional and gastrointestinal effects. J. Anim. Feed Sci. 1998, 7, 25-33.

236. Blank, R.; Muller-Siegwardt, B.; Wolffram, S. Sanguinarine does not influence availability or metabolism of tryptophan in pigs. Livest. Sci. 2010, 134, 24-26. [CrossRef]

237. Stiborova, M.; Vostalova, J.; Zdarilova, A.; Ulrichova, J.; Hudecek, J.; Tschirner, K.; Simanek, V. Macleaya cordata extract and sangrovit genotoxicity. Assessment in vivo. Biomed. Pap. Med. Fac. Univ. Palacky Olomouc Czechoslov. 2008, 152, 35-39. [CrossRef]

238. Kantas, D.; Papatsiros, V.G.; Tassis, P.D.; Athanasiou, L.V.; Tzika, E.D. The effect of a natural feed additive (Macleaya cordata), containing sanguinarine, on the performance and health status of weaning pigs. Anim. Sci. J. 2015, 86, 92-98. [CrossRef] [PubMed]

239. Vieira, S.; Oyarzabal, O.; Freitas, D.; Berres, J.; Pena, J.; Torres, C.; Coneglian, J. Performance of broilers fed diets supplemented with sanguinarine-like alkaloids and organic acids. J. Appl. Poult. Res. 2008, 17, 128-133. [CrossRef]

240. Rawling, M.D.; Merrifield, D.L.; Davies, S.J. Preliminary assessment of dietary supplementation of sangrovit ${ }^{\circledR}$ on red tilapia (Oreochromis niloticus) growth performance and health. Aquaculture 2009, 294, 118-122. [CrossRef]

241. Pickler, L.; Beirão, B.C.; Hayashi, R.M.; Durau, J.F.; Lourenço, M.C.; Caron, L.F.; Santin, E. Effect of sanguinarine in drinking water on salmonella control and the expression of immune cells in peripheral blood and intestinal mucosa of broilers. J. Appl. Poult. Res. 2013, 22, 430-438. [CrossRef]

242. Robbins, R.C.; Artuso-Ponte, V.C.; Moeser, A.J.; Morrow, W.E.M.; Spears, J.W.; Gebreyes, W.A. Effects of quaternary benzo[c]phenanthridine alkaloids on growth performance, shedding of organisms, and gastrointestinal tract integrity in pigs inoculated with multidrug-resistant Salmonella spp.. Am. J. Vet. Res. 2013, 74, 1530-1535. [CrossRef] [PubMed]

243. Taylor, S.; Haldorson, G. A review of equine sarcoid. Equine Vet. Educ. 2013, 25, 210-216. [CrossRef]

244. Nogueira, S.A.; Torres, S.M.; Malone, E.D.; Diaz, S.F.; Jessen, C.; Gilbert, S. Efficacy of imiquimod 5\% cream in the treatment of equine sarcoids: A pilot study. Vet. Dermatol. 2006, 17, 259-265. [CrossRef] [PubMed]

245. Pettersson, C. Utvärtes Behandling av Sarkoider på häst Med Aldara tm Eller Xxterra tm. slu. Ph.D. Thesis, Swedish University of Agricultural Sciences, Uppsala, Sweden, 1 February 2008.

246. Wilford, S.; Woodward, E.; Dunkel, B. Owners' perception of the efficacy of newmarket bloodroot ointment in treating equine sarcoids. Can. Vet. J. 2014, 55, 683-686. [PubMed]

247. Childress, M.O.; Burgess, R.C.; Holland, C.H.; Gelb, H.R. Consequences of intratumoral injection of a herbal preparation containing blood root (Sanguinaria canadensis) extract in two dogs. J. Am. Vet. Med. Assoc. 2011, 239, 374-379. [CrossRef] [PubMed]

248. Karjalainen, K.; Kaivosoja, S.; Seppa, S.; Knuuttila, M. Effects of sanguinaria extract on leucocytes and fibroblasts. Proc. Finn.Dent. Soc. 1988, 84, 161-165. [PubMed]

249. Damm, D.D.; Curran, A.; White, D.K.; Drummond, J.E. Leukoplakia of the maxillary vestibule-An association with viadent? Oral Surg. Oral Med. 1999, 87, 61-66. [CrossRef]

250. Weatherell, J.A.; Robinson, C.; Rathbone, M. The flow of saliva and its influence on the movement, deposition and removal of drugs administered to the oral cavity. Drugs Pharm. Sci. 1996, 74, 157-189.

251. Munro, I.C.; Delzell, E.S.; Nestmann, E.R.; Lynch, B.S. Viadent usage and oral leukoplakia: A spurious association. Regul. Toxicol. Pharmacol. 1999, 30, 182-196. [CrossRef] [PubMed]

252. Eversole, L.R.; Eversole, G.M.; Kopcik, J. Sanguinaria-associated oral leukoplakia: Comparison with other benign and dysplastic leukoplakic lesions. Oral Surg. Oral Med. 2000, 89, 455-464. [CrossRef]

253. Allen, C.L.; Loudon, J.; Mascarenhas, A.K. Sanguinaria-related leukoplakia: Epidemiologic and clinicopathologic features of a recently described entity. Gen. Dent. 2001, 49, 608-614. [PubMed]

254. Eley, B.M. Antibacterial agents in the control of supragingival plaque-A review. Br. Dent. J. 1999, 186, 286-296. [PubMed]

255. Jacobs, J.; Herman, P.; Heron, K.; Olsen, S.; Vaughters, L. Homeopathy for menopausal symptoms in breast cancer survivors: A preliminary randomized controlled trial. J. Altern. Complement. Med. 2005, 11, 21-27. [CrossRef] [PubMed] 
256. Milazzo, S.; Russell, N.; Ernst, E. Efficacy of homeopathic therapy in cancer treatment. Eur. J. Cancer 2006, 42, 282-289. [CrossRef] [PubMed]

257. Bordet, M.F.; Colas, A.; Marijnen, P.; Masson, J.L.; Trichard, M. Treating hot flushes in menopausal women with homeopathic treatment-Results of an observational study. Homeopathy 2008, 97, 10-15. [CrossRef] [PubMed]

258. Hielm-Björkman, A.; Tulamo, R.-M.; Salonen, H.; Raekallio, M. Evaluating complementary therapies for canine osteoarthritis-Part II: A homeopathic combination preparation (zeel $\left.{ }^{\circledR}\right)$. Evid. Based Complement. Altern. Med. 2009, 6, 465-471. [CrossRef] [PubMed]

259. Nahler, G.; Metelmann, H.; Sperber, H. Behandlung der gonarthrose mit zeel [r] comp.-ergebnisse einer randomisierten, kontrollierten klinischen pruefung im vergleich zu hyaluronsaeure. Orthop. Pract. 1996, 32, 354-359.

260. Oral Treatment of Arthritis of the Knee with Zeel ${ }^{\circledR}$ Comp. Available online: http://www.homotoxicology. net/Documents/Brochures/Zeel.pdf (accessed on 16 August 2016).

261. Birnesser, H.; Klein, P.; Weiser, M. A modern homeopathic medication works as well as COX 2 inhibitors. Der Allg. 2003, 25, 261-264.

262. Mohs, F.; Guyer, M. Pre-excisional fixation of tissues in the treatment of cancer in rats. Cancer Res. 1941, 1, $49-51$.

263. Kimyai-Asadi, A.; Goldberg, L.H.; Jih, M.H. Accuracy of serial transverse cross-sections in detecting residual basal cell carcinoma at the surgical margins of an elliptical excision specimen. J. Am. Acad. Dermatol. 2005, 53, 468-473. [CrossRef] [PubMed]

264. Trost, L.B.; Bailin, P.L. History of mohs surgery. Dermatol. Clin. 2011, 29, 135-139. [CrossRef] [PubMed]

265. Mohs, F.E. Chemosurgery: A microscopically controlled method of cancer excision. Arch. Surg. 1941, 42, 279-295. [CrossRef]

266. Mohs, F.E.; Caruso, R. Chemosurgery and skin cancer. AORN J. 1971, 13, 89-97. [CrossRef]

267. Mohs, F.E. Chemosurgery: Microscopically controlled surgery for skin cancer-Past, present and future. J. Dermatol. Surg. Oncol. 1978, 4, 41-54. [CrossRef] [PubMed]

268. Mohs, F.E. Chemosurgery for skin cancer: Fixed tissue and fresh tissue techniques. Arch. Dermatol. 1976, 112, 211-215. [CrossRef] [PubMed]

269. Farrow, R.T. Odyssey of an American cancer specialist of a hundred years ago. Bull. Hist. Med. 1949, 23, 236-262.

270. Middlesex Hospital. Report of the Surgical Staff of the Middlesex Hospital to the Weekly Board of Governors upon the Treatment of Cancerous Diseases in the Hospital on the Plan Introduced by dr. Fell; John Churchill.: London, $\mathrm{UK}, 1857$.

271. Journal of the American Medical Association. Bureau of investigation, comment on court opinion that internal cancer can be cured with medicine. JAMA 1951, 145, 252-253.

272. Hoxsey, H.M. You Don't Have to Die; Milestone Books: New York, NY, USA, 1956.

273. Austin, S.; Baumgartner, E.; DeKadt, S. Long term follow-up of cancer patients using contreras, hoxsey and gerson therapies. J. Naturop. Med. 1995, 5, 74-76.

274. Richardson, M.A.; Russell, N.C.; Sanders, T.; Barrett, R.; Salveson, C. Assessment of outcomes at alternative medicine cancer clinics: A feasibility study. J. Altern. Complement. Med. 2001, 7, 19-32. [CrossRef] [PubMed]

275. Jellinek, N.; Maloney, M.E. Escharotic and other botanical agents for the treatment of skin cancer: A review. J. Am. Acad. Dermatol. 2005, 53, 487-495. [CrossRef] [PubMed]

276. Cansema \& Escharotics FAQ 200 Constituents; FAQ 206 What are the Side Effects; FAQ 215 Can it Be Used to Treat Melanoma; FAQ 222 Success Rate with Skin Cancer. Available online: http:/ /www.altcancer.com/ faqcan.htm (accessed on 15 July 2016).

277. Earth Circle Creation. Available online: http://shop.earthcirclecreations.com/product_info.php?cPath=61\& products_id=263 (accessed on 15 July 2016).

278. Ong, N.C.; Sham, E.; Adams, B.M. Use of unlicensed black salve for cutaneous malignancy. Med. J. Aust. 2014, 200, 314. [CrossRef] [PubMed]

279. McDaniel, S.; Goldman, G.D. Consequences of using escharotic agents as primary treatment for nonmelanoma skin cancer. Arch. Dermatol. 2002, 138, 1593-1596. [CrossRef] [PubMed]

280. Cienki, J.J.; Zaret, L. An internet misadventure: Bloodroot salve toxicity. J. Altern. Complement. Med. 2010, 16, 1125-1127. [CrossRef] [PubMed] 
281. Sivyer, G.W.; Rosendahl, C. Application of black salve to a thin melanoma that subsequently progressed to metastatic melanoma: A case study. Dermatol. Pract. Concept. 2014, 4, 77-80. [CrossRef] [PubMed]

282. Osswald, S.S.; Elston, D.M.; Farley, M.F.; Alberti, J.G.; Cordero, S.C.; Kalasinsky, V.F. Self-treatment of a basal cell carcinoma with "black and yellow salve". J. Am. Acad. Dermatol. 2005, 53, 509-511. [CrossRef] [PubMed]

283. Hopkins, A.L.; Mason, J.S.; Overington, J.P. Can we rationally design promiscuous drugs? Curr. Opin. Struct. Biol. 2006, 16, 127-136. [CrossRef] [PubMed]

284. Hopkins, A.L. Network pharmacology: The next paradigm in drug discovery. Nat. Chem. Biol. 2008, 4, 682-690. [CrossRef] [PubMed]

285. Ahmad, N.; Gupta, S.; Husain, M.M.; Heiskanen, K.M.; Mukhtar, H. Differential antiproliferative and apoptotic response of sanguinarine for cancer cells versus normal cells. Clin. Cancer Res. 2000, 6, 1524-1528. [PubMed]

286. Krstin, S.; Peixoto, H.S.; Wink, M. Combinations of alkaloids affecting different molecular targets with the saponin digitonin can synergistically enhance trypanocidal activity against Trypanosoma brucei. Antimicrob. Agents Chemother. 2015, 59, 7011-7017. [CrossRef] [PubMed]

287. Kulp, M.; Bragina, O. Capillary electrophoretic study of the synergistic biological effects of alkaloids from Chelidonium majus 1. In normal and cancer cells. Anal. Bioanal. Chem. 2013, 405, 3391-3397. [CrossRef] [PubMed]

288. Braakhuis, B.J.; Tabor, M.P.; Kummer, J.A.; Leemans, C.R.; Brakenhoff, R.H. A genetic explanation of slaughter's concept of field cancerization evidence and clinical implications. Cancer Res. 2003, 63, 1727-1730. [PubMed]

289. Ansari, K.M.; Das, M. Potentiation of tumour promotion by topical application of argemone oil/isolated sanguinarine alkaloid in a model of mouse skin carcinogenesis. Chem. Biol. Interact. 2010, 188, 591-597. [CrossRef] [PubMed]

290. Ahsan, H.; Reagan-Shaw, S.; Eggert, D.M.; Tan, T.C.; Afaq, F.; Mukhtar, H.; Ahmad, N. Protective effect of sanguinarine on ultraviolet B-mediated damages in SKH-1 hairless mouse skin: Implications for prevention of skin cancer. Photochem. Photobiol. 2007, 83, 986-993. [CrossRef] [PubMed]

291. Reagan-Shaw, S.; Breur, J.; Ahmad, N. Enhancement of UVB radiation-mediated apoptosis by sanguinarine in hacat human immortalized keratinocytes. Mol. Cancer Ther. 2006, 5, 418-429. [CrossRef] [PubMed]

292. Gesler, W.M. Therapeutic landscapes: Medical issues in light of the new cultural geography. Soc. Sci. Med. 1992, 34, 735-746. [CrossRef]

293. Harris, P.; Cooper, K.; Relton, C.; Thomas, K. Prevalence of complementary and alternative medicine (CAM) use by the general population: A systematic review and update. Int. J. Clin. Pract. 2012, 66, 924-939. [CrossRef] [PubMed]

294. Bent, S. Herbal medicine in the united states: Review of efficacy, safety, and regulation. J. Gen. Intern. Med. 2008, 23, 854-859. [CrossRef] [PubMed]

295. Board, S. Botanical medicines-The need for new regulations. N. Engl. J. Med. 2002, 347, 2073-2076.

296. Coghlan, M.L.; Maker, G.; Crighton, E.; Haile, J.; Murray, D.C.; White, N.E.; Byard, R.W.; Bellgard, M.I.; Mullaney, I.; Trengove, R. Combined DNA, toxicological and heavy metal analyses provides an auditing toolkit to improve pharmacovigilance of traditional Chinese medicine (TCM). Sci. Rep. 2015, 5, 17475. [CrossRef] [PubMed]

(C) 2016 by the authors; licensee MDPI, Basel, Switzerland. This article is an open access article distributed under the terms and conditions of the Creative Commons Attribution (CC-BY) license (http://creativecommons.org/licenses/by/4.0/). 